\title{
Lobster processing by-products as valuable bioresource of marine functional ingredients, nutraceuticals, and pharmaceuticals
}

Trung T. Nguyen ${ }^{1,2,3^{*}}$, Andrew R. Barber ${ }^{1,2}$, Kendall Corbin ${ }^{1,2,4}$ and Wei Zhang ${ }^{1,2}$

\begin{abstract}
The worldwide annual production of lobster was 165,367 tons valued over $\$ 3.32$ billion in 2004, but this figure rose up to 304,000 tons in 2012. Over half the volume of the worldwide lobster production has been processed to meet the rising global demand in diversified lobster products. Lobster processing generates a large amount of by-products (heads, shells, livers, and eggs) which account for $50-70 \%$ of the starting material. Continued production of these lobster processing by-products (LPBs) without corresponding process development for efficient utilization has led to disposal issues associated with costs and pollutions. This review presents the promising opportunities to maximize the utilization of LPBs by economic recovery of their valuable components to produce high value-added products. More than 50,000 tons of LPBs are globally generated, which costs lobster processing companies upward of about $\$ 7.5 \mathrm{million} /$ year for disposal. This not only presents financial and environmental burdens to the lobster processors but also wastes a valuable bioresource. LPBs are rich in a range of high-value compounds such as proteins, chitin, lipids, minerals, and pigments. Extracts recovered from LPBs have been demonstrated to possess several functionalities and bioactivities, which are useful for numerous applications in water treatment, agriculture, food, nutraceutical, pharmaceutical products, and biomedicine. Although LPBs have been studied for recovery of valuable components, utilization of these materials for the large-scale production is still very limited. Extraction of lobster components using microwave, ultrasonic, and supercritical fluid extraction were found to be promising techniques that could be used for large-scale production. LPBs are rich in high-value compounds that are currently being underutilized. These compounds can be extracted for being used as functional ingredients, nutraceuticals, and pharmaceuticals in a wide range of commercial applications. The efficient utilization of LPBs would not only generate significant economic benefits but also reduce the problems of waste management associated with the lobster industry. This comprehensive review highlights the availability of the global LPBs, the key components in LPBs and their current applications, the limitations to the extraction techniques used, and the suggested emerging techniques which may be promising on an industrial scale for the maximized utilization of LPBs.
\end{abstract}

Keywords: Lobster processing by-products, Marine functional ingredients and nutraceuticals, Chitin and chitosan, Astaxanthin, Lobster flavors, Lobster lipids, Lobster protein

\section{Global lobster processing industry generates a large amount of by-products}

In 2004, the global production of lobster yielded 165,367 tons (Holmyard and Franz 2006) which had an

\footnotetext{
*Correspondence: nguy0514@flinders.edu.au

${ }^{1}$ Centre for Marine Bioproducts Development, Flinders University,

Adelaide, Australia

Full list of author information is available at the end of the article
}

estimated value of $\$ 3.32$ billion. Over the last decade, these figures have been rising to reach 304,000 tons (captures and aquaculture) in 2012 (Sabatini 2015). Lobster production can be found across the world; however, the majority of production is concentrated in only three countries: Canada (34\%), America (29\%), and Australia (11\%) (Fig. 1) (Annie and McCarron 2006). The four main commercial lobster species produced are the American lobster (Homarus americanus), Tropical or Spiny lobster 


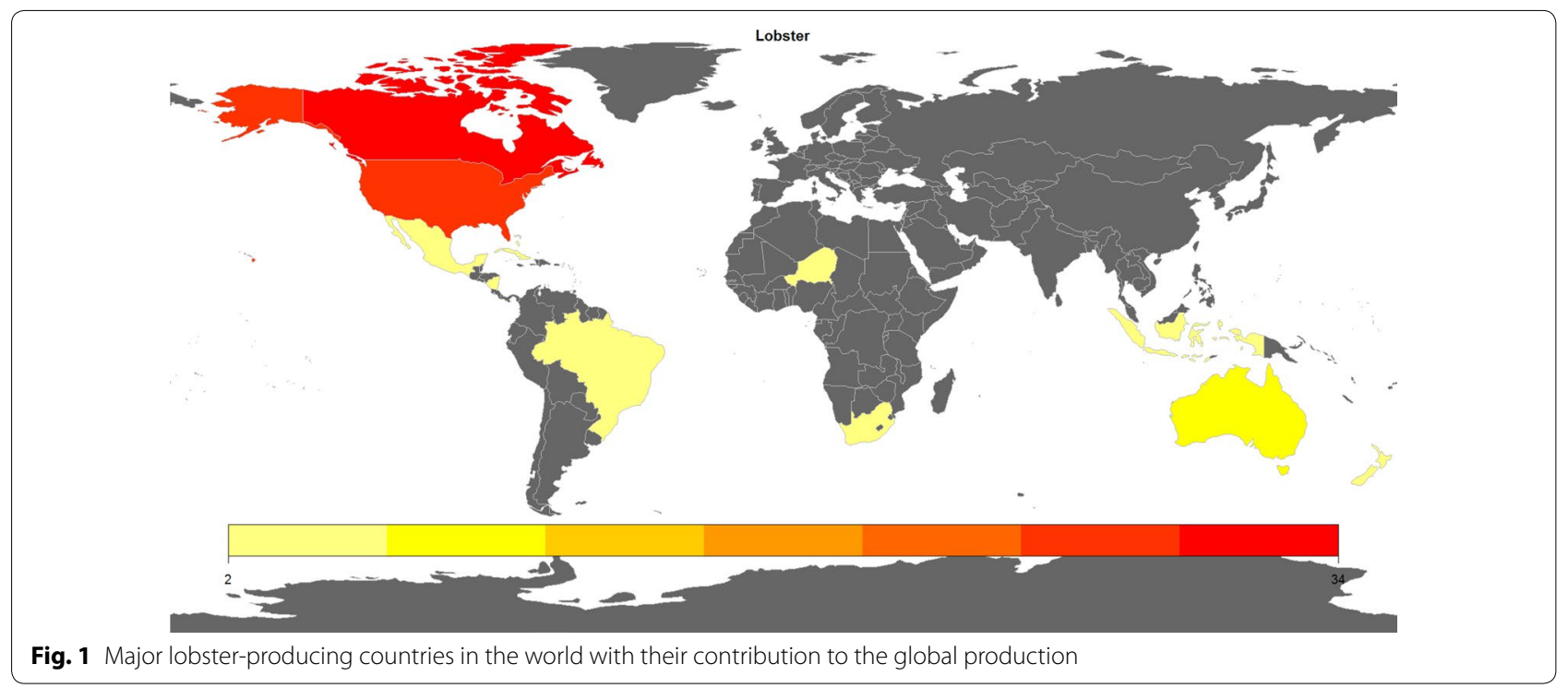

(Panulirus sp), Rock lobster (Jasus sp), and European lobster (Homarus gammarus).

The most abundant species produced in the world is the American lobster which is mainly harvested in Canada and America (Fig. 2) (Annie and McCarron 2006). In 2012, both Canada and America produced 140,000 tons of lobsters (Thériault et al. 2013) with the majority (74,790 tons, valued at $\$ 662.8$ million) originating from Canada (Ilangumaran 2014). The second-most readily available commercial species is Spiny lobster accounting for $38 \%$ of the global production, while the contribution of the Rock lobster is $6 \%$. This latter species is predominantly harvested from Australia, which includes four main commercial species: Western rock lobster $(60 \%)$, Southern rock lobster (30\%), Tropical rock lobster (8\%),

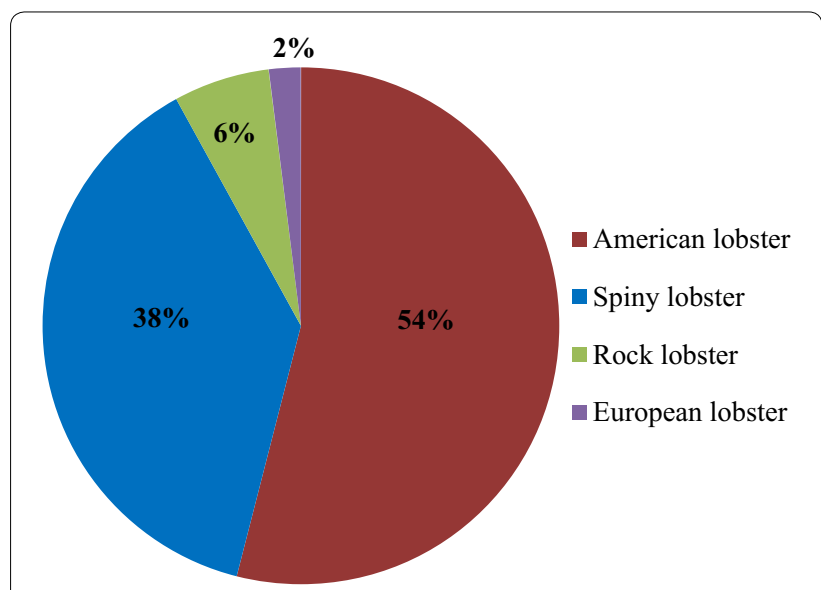

Fig. 2 The four main commercial lobster species in the world and eastern rock lobster (2\%) with the total yield about 9650 tons annually (Gary 2012). The term 'Rock lobster' has been used to describe lobster species such as Jasus and Panulirus which are caught by Australian lobster fishery (Holmyard and Franz 2006).

As lobster are consumed globally but are predominantly produced in a few countries, there is a rapidly growing export market of lobsters. Although live lobsters are preferred by consumers around the world, the export of live lobsters is limited due to its high cost, complexity, and high rates of mortality and loss during shipment. In contrast, processed lobsters has several advantages such as ease of handling in transport and storage, extended shelf life, availability of the products, convenience in food preparation, and higher potential to adding value to raw products. This ease in handling and increase in profits have resulted in over half of the landed lobster in the major lobster-producing countries being processed (Barker and Rossbach 2013; Denise and Jason 2012; Ilangumaran 2014).

Lobsters are commercially processed into various products such as fresh lobster meat, picked lobster meat, canned lobster, lobster medallion, whole cooked lobsters, and frozen lobsters (Holmyard and Franz 2006). During processing, the inedible parts are removed including heads, shells, roe, and livers (Fig. 3), and are traditionally discarded. The types and proportion of lobster processing by-products (LPBs) generated vary depending on the processing process but on average accounts for around $75 \%(\mathrm{w} / \mathrm{w})$ of the starting material (Table 1$)$. As a result of this, the annual estimate of LPBs produced from the major lobster processing countries (Canada, America, and Australia) is about 50,000 tons. 


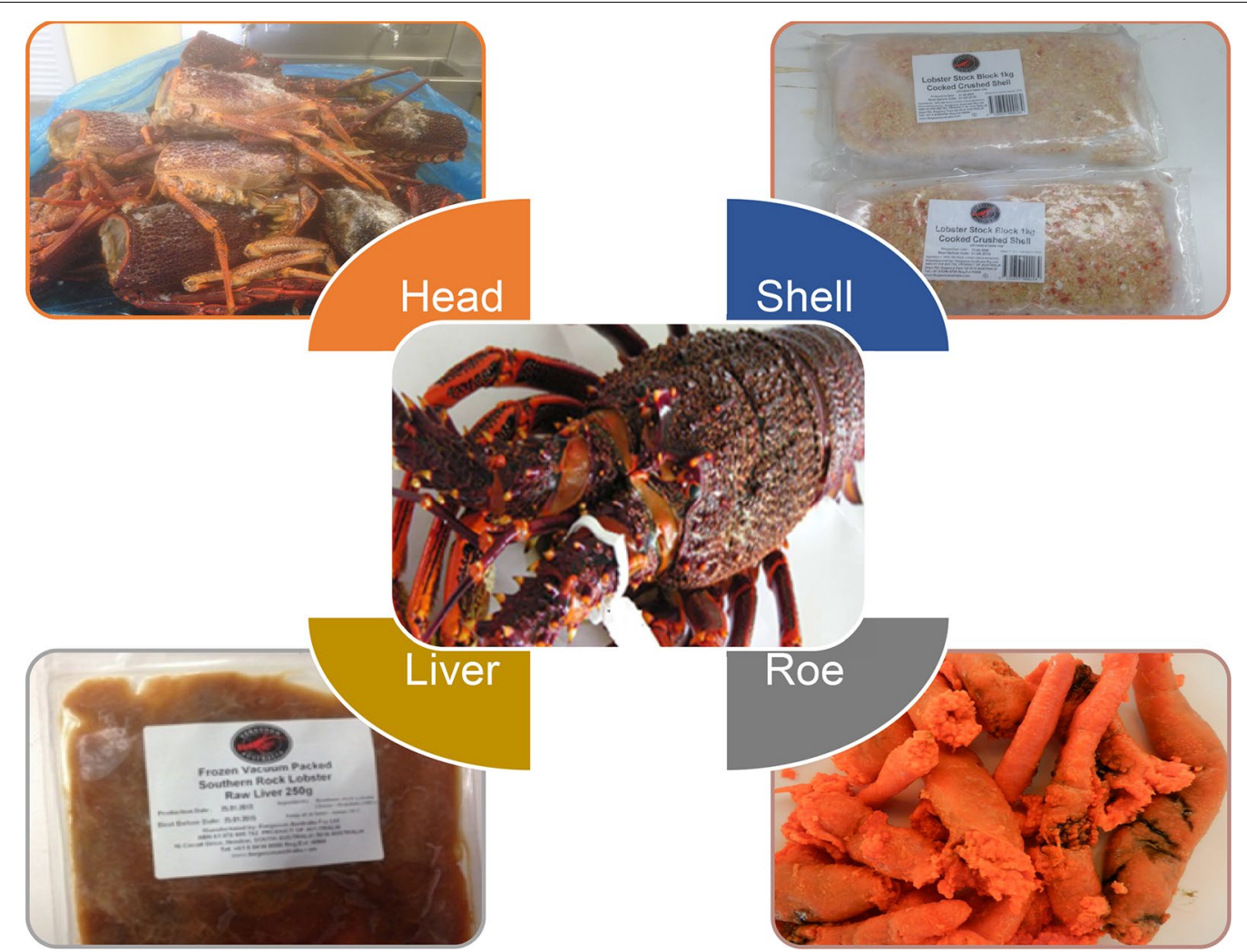

Fig. 3 Different by-products (heads, livers, shells, and eggs) generated from the commercial lobster processing industry

Table 1 The amount of by-products generated from the different lobster processing industries

\begin{tabular}{|c|c|c|c|}
\hline Lobster processing industries & Types of by-products & $\begin{array}{l}\text { Percentage of by-products based } \\
\text { on starting material (\%) }\end{array}$ & References \\
\hline Canning of Canadian lobsters & Lobster body & 45 & Ross (1927) \\
\hline Canadian lobster meat & $\begin{array}{l}\text { Lobster head, hard carapace, viscera, } \\
\text { mandibles, and gills }\end{array}$ & $>75$ & Tu (1991) \\
\hline Brazilian lobster tails & Lobster head (cephalothorax) & 75 & Vieira et al. (1995) \\
\hline $\begin{array}{l}\text { Fresh meat picked from Australian rock } \\
\text { lobster }\end{array}$ & Lobster head, shell, and viscera & 60 & Lien (2004) \\
\hline $\begin{array}{l}\text { High hydrostatic pressure production of } \\
\text { American lobster meat }\end{array}$ & Lobster shells, viscera, residual meat & $75-80$ & Denise and Jason (2012) \\
\hline
\end{tabular}

To maximize the production yield and profit, lobster processors have begun to utilize some LPBs to produce several products such as lobster tomalley, lobster roe, lobster concentrate, and lobster meat paste (Holmyard and Franz 2006). However, the amount of LPBs being utilized compared to the tons generated is still very limited. The slow uptake and growth of industries using this waste material may be attributed to the current lack of efficient and standardized techniques to transform these materials into a marketable form. Thus, the vast majority of LPBs is discarded at a cost incurred by lobster processors. In some countries such as Australia, this fee can be in excess of $\$ 150$ per ton (Knuckey 2004; Yan and Chen 2015). In addition, not only is the disposal of lobster byproducts and waste management a financial burden for lobster processing companies globally costing an estimated $\$ 7.5$ million per year, but is also considered to be environmentally unfriendly due to dumping in the landfill or the sea (Chen et al. 2016; Yan and Chen 2015). This could create disposal problems and environmental pollutions (Hamed et al. 2016; Sayari et al. 2016). Moreover, this underutilizes a marine bioresource that could be mined to produce several valuable ingredients for a wide range of commercial industries. Shell waste, for 
instance, has been considered as a source of useful chemicals for many commercial applications (Chen et al. 2016; Yan and Chen 2015). Crude crustacean shells or chitin derived from chitin shells could be used for production of low molecular weight chitosan and chitin oligomers with numerous applications employing simple processes (Chen et al. 2017; Zhang and Yan 2016). As a result, the utilization of these LPBs for recovery of marine functional ingredients, nutraceuticals, and pharmaceuticals for incorporation into highly value-added products could bring significantly both economic and environmental benefits to regions where lobsters are processed.

\section{LPBs containing several valuable components Proteins}

By-products generated from lobster processing industry are protein-rich sources for recovery. For example, the lobster liver (green) contains up to $41 \%$ protein on a dry basis (Nguyen et al. 2015), while the lobster head containing residual meats (body, breast, and leg) up to $20 \%$ of the lobster weight (Vieira et al. 1995) would be another major high-quality protein source. In addition, lobster shells (carapace) constituted by a large amount of proteins (about 25\%) are also another potential source of protein for mining (Nguyen et al. 2016).

The amino acid profile of crustacean protein such as lobster is comparable to that of red meat protein, but it contains more nonprotein nitrogen (amino acids, small peptides, trimethylamine oxide (TMAO), trimethylamine, creatine, creatinine, and nucleotides) ranging from $10-40 \%$. Thus, crustacean protein is more palatable than meat proteins (Venugopal 2009). As compared with other marine species such as finfish, proteins derived from crustacean generally contain larger amounts of arginine, glutamic acid, glycine, and alanine; this makes crustacean proteins more palatable than finfish proteins. Due to its ideal essential amino acid pattern, moreover, the nutritional value of crustacean protein is equal to or better than that of milk protein (casein) and red meat proteins (Venugopal 2009) or soya-bean proteins (Yan and Chen 2015). Lobster proteins are rich in all the essential amino acids (EAAs) with its proportion approximately reaching $41.2 \%$ for protein in lobster head meat (Vieira et al. 1995) and 34\% for lobster shell protein (Nguyen et al. 2016). Especially, the nutritional value of lobster protein is fortified significantly by its natural combination with a large amount of astaxanthin $(295 \mu \mathrm{g} / \mathrm{g})$ as a powerful antioxidant to form a protein complex known as carotenoprotein. This protein was found in lobster shells with high proportion (16\%) (Tu et al. 1991).

Apart from its high delicacy, palatability, and nutritional values, lobster proteins have also been shown to have excellent functional properties. For example, protein derived from lobster head meats has been shown to have excellent wettability, high solubility, and emulsification (Vieira et al. 1995). Solubility of lobster shell protein (LSP) recovered either by aqueous extraction or enzymatic digestion was over $93 \%$, which is independent of the $\mathrm{pH}$ value and the ionic strength of the solution used (Nguyen et al. 2016; Oviedo et al. 1982). High water binding of LSP was also reported by the fact that beef mince when added with $2 \%$ of LSP resulted in its water-binding capacity being 2.5 times higher than that when added with egg white protein (Nguyen et al. 2016). In addition, lobster protein hydrolysate (LPH) performed an excellent emulsifying property (69.7 vs $50.3 \mathrm{~m}^{2} / \mathrm{g}$ of cow gelatin) (He et al. 2016).

\section{Chitin and chitin derivatives}

Chitin is a cationic linear polysaccharide composed of $\beta$-(1-4)-linked $N$-acetyl-D-glucosamine monomers (Fig. 4a) and is the second-most abundant biopolymer only after cellulose in the biosphere (Kumar 2000; Kurita 2006). Chitin is present in lobster shells with contents of 16-23\% in the form of $\alpha$-chitin (Lien 2004; Rinaudo 2006; Tu 1991). Chito san represents a family of $N$-deacetylated chitin with various degrees of deacetylation (Fig. 4b), while chito-oligosaccharides (COS) are derived from chitin and chitosan by either chemical or enzymatic hydrolysis.

LPBs such as lobster shell waste are abundant and rich in chitin attributing to its importance as a potential source of commercial chitin. The utilization of LPBs for recovery of chitin has received a great interest since chitin is a natural biopolymer with high biodegradability, biocompatibility, and nontoxicity (Karagozlu and Kim 2015). Derivatives generated from chitin such as chitosan and COS have significant potential economic values with more than 200 applications in water treatment, food, agriculture, healthcare products, environmental sector, pharmaceuticals, and biomedicine (Kaur and Dhillon 2013; Muzzarelli 1989; Sandford 1989; Synowiecki and Al-Khateeb 1997). There is an increasing global demand for chitin and chitin derivatives with the estimated quantities of 11,400 tons for chitin and 33,400 ton for chitin derivatives (Hayes 2012). Economic value of chitin and chitin derivatives was $\$ 2.0$ billion in 2016 , but this figure is estimated to increase significantly to $\$ 4.2$ billion by 2021 (Pathak 2017).

\section{Lipids}

Lipid is another valuable constituent of LPBs due to its nutraceutical-rich composition (polyunsaturated fatty acids (PUFAs); $\omega-3$ fatty acids; and lipid-soluble vitamins). Lobster body contains less than $2 \%$ of lipids (Shahidi 2006), but concentration of this constituent is significantly higher in some other parts of the lobsters. Cephalothorax, a by-product generated from lobster processing industry, 


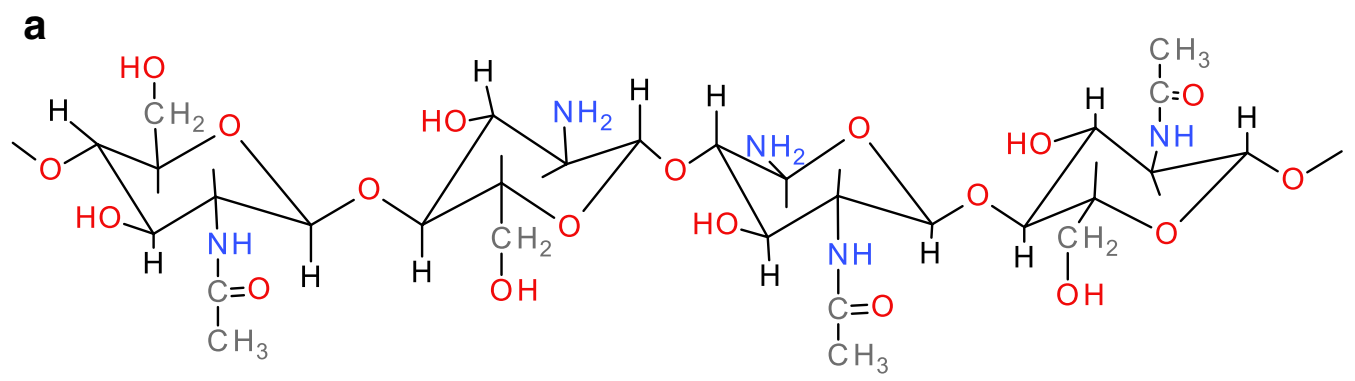

b

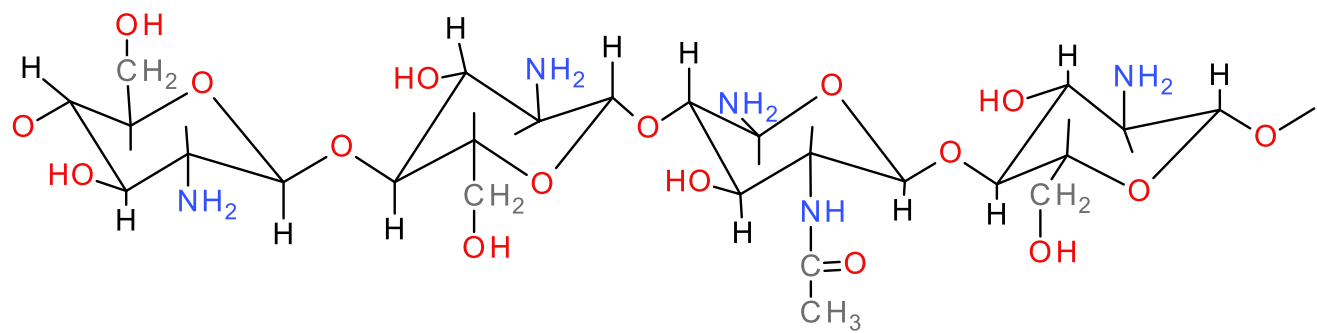

Fig. 4 The chemical structure of the main polymer present in lobster shell: chitin (a), and the $N$-deacetylation form of chitin, chitosan (b)

is one of the lipid-rich parts of lobster with various lipid contents depending on lobster habitat, season, and species. In summer season, Norway lobster cephalothorax has the highest lipid content with a value of $11.5 \%$ (Albalat et al. 2016). Cephalothorax of Norway lobster contains lower lipid content than that of Australian lobster which accounts for up to $19.4 \%$ (Tsvetnenko et al. 1996). Lobster liver is another lipid-rich part of lobster with the lipid content of which is up to 24.3\% (Nguyen et al. 2015). Among crustaceans, LPBs contain more lipids than crab and shrimp by-products, while this value is comparable to that of krill being used for lipid production (Albalat et al. 2016). Lobster lipids are rich in PUFAs and $\omega-3$ fatty acids as reported in the study of Tsvetnenko et al. (1996): lipids extracted from lobster cephalothorax contained $22.6 \%$ of fatty acids in which $\omega-3$ fatty acids accounted for $50.8 \%$. However, the amounts of PUFAs and $\omega-3$ fatty acids were significantly higher ( 22.6 vs $31.3 \%, 50.8$ vs $58 \%$ ) when lipids were recovered from lobster livers using supercritical carbon dioxide $\left(\mathrm{SC}-\mathrm{CO}_{2}\right)$ extraction technique (Nguyen et al. 2015). Richness of PUFAs and $\omega-3$ fatty acids in lobster lipids is comparable to that of menhaden lipids (Tsvetnenko et al. 1996) or even higher than that of krill lipids (Albalat et al. 2016). Particularly, lobster lipids also contain carotenoids and astaxanthin with concentrations of 70.4 and $41.6 \mu \mathrm{g} / \mathrm{mL}$, respectively (Nguyen 2017).

\section{Astaxanthin}

Astaxanthin is the oxygenated derivatives of carotenoids occurring widely and naturally in marine organisms including crustaceans (lobster, shrimp, crab, and krill) and fish (salmon, sea bream). Astaxanthin is one of the first pigments isolated and characterized from lobster (Kuhn and Soerensen 1938). By-products generated from lobsters, shrimps, crabs, crayfish, and krill are a vital source of natural carotenoids, mainly astaxanthin (Sachindra et al. 2007). Apart from containing a large proportion of mineral salts (15-35\%), proteins $(25-50 \%)$, chitin (25-35\%), and lipids (19.4-24.3\%) (Lee and Peniston 1982; Nguyen et al. 2015), LPBs are also constitutive of a certain amount of carotenoids. Astaxanthin content in crustaceans varies depending on species, season, and environmental grown conditions, but lobster by-products contain double the amount of astaxanthin compared with shrimp (Table 2). Astaxanthin exists in a free form and/or in a complex form known as carotenoprotein. Due to their containing a high proportion of astaxanthin, LPBs have been utilized for the recovery of astaxanthin

Table 2 Total astaxanthin in by-products of lobsters compared with other crustacean species

\begin{tabular}{|c|c|c|}
\hline Source & $\begin{array}{l}\text { Total astaxanthin } \\
(\mathrm{mg} / 100 \mathrm{~g})\end{array}$ & References \\
\hline Shrimp (P. borealis) & 4.97 & Torrissen et al. (1981) \\
\hline Crawfish (P. clarkii) & 15.30 & Meyers and Bligh (1981) \\
\hline $\begin{array}{l}\text { Backs snow crab (Ch. } \\
\text { opilio) }\end{array}$ & 11.96 & $\begin{array}{l}\text { Shahidi and Synowiecki } \\
\text { (1991) }\end{array}$ \\
\hline $\begin{array}{l}\text { Lobster (Homarus } \\
\text { americanus) }\end{array}$ & 9.80 & Tu (1991) \\
\hline
\end{tabular}


(Auerswald and Gäde 2008; Gäde and Auerswald 2005). Two processes were patented for astaxanthin extraction from lobster heads (Kozo 1997; Sunda et al. 2012), while food-grade astaxanthin was recovered from the shells of American lobster generated from the high hydrostatic pressure process (Denise and Jason 2012).

\section{Various applications of extracts derived from LPBs}

The most common traditional utilization of LPBs is their use as a source of nutrients for soil amendment considered as an informal way of disposal (Cousins 1997), but it brings no economic benefits for lobster producers. Recently, LPBs have been studied as an important bioresource in the recovery of marine functional ingredients, nutraceuticals, and pharmaceuticals for numerous applications (Table 3).

\section{Lobster protein: dietary protein supplement, food functional ingredients, or flavorings}

The recovery of edible meat from lobster by-products is not novel. However, the use of these by-products as a source of sustainable proteins for food products has been less explored. In one study, the meats (body meat, breast meat, leg meat, roe, and liver) recovered from Canadian lobster by-products were used to create a canned food product and lobster paste (Ross 1927). Although the final products prepared from these protein sources were flavorrich, nutritious, and palatable, the feasibility for commercialization was found impractical as the methods used for residual meat recovery were inefficient. To address this key problem, a process was developed for the recovery of foodgrade lobster meats from spiny lobster head by-product by freezing the heads and later cutting them for meat picking. The recovered lobster meat was sold as high-value, gourmet food products (Meyers and Machada 1978).

The actual flavor of lobster itself is considered a highly valued product, which may be extracted and sold, creating an additional processing stream for lobster wastes. The practice of converting LPBs into natural lobster flavors has been standardized and has now become an established industrial practice. The cephalothorax of Brazilian lobster by-products

Table 3 The different types of lobster by-products generated with their valuable components for potential areas of applications

\begin{tabular}{|c|c|c|c|}
\hline Lobster by-products & $\begin{array}{l}\text { Functional ingredients, } \\
\text { nutraceuticals, pharmaceuticals }\end{array}$ & Suggested application areas & References \\
\hline \multirow[t]{9}{*}{ Lobster shells (carapace) } & Chitin, chitosan & Water treatment & Gustavo et al. (2005); Pathiraja (2014) \\
\hline & $\begin{array}{l}\text { Chitin, chitosan, chitin-oligosaccha- } \\
\text { rides, chitosan-oligosaccharide }\end{array}$ & Agriculture & $\begin{array}{l}\text { Borges et al. (2000); Falcón et al. (2002); } \\
\text { Cabrera and Van Cutsem (2005); Falcón } \\
\text { Rodríguez et al. (2010); llangumaran (2014) }\end{array}$ \\
\hline & Chitosan, chitosan film & Food processing and preservative & Defang et al. (2001); Garcla et al. (2015) \\
\hline & $\begin{array}{l}\text { Water-soluble chitosan, chitosan } \\
\text { particles }\end{array}$ & Pharmacy & Safitri et al. (2014); De la Paz et al. (2015) \\
\hline & Chitosan film & Biomedicine & Malho et al. (2014); Qi (2015) \\
\hline & Carotenoprotein & Aquafeed & $\begin{array}{l}\text { Dauphin (1991); Simpson et al. (1993); Tu } \\
\text { (1991); Tu et al. (1991) }\end{array}$ \\
\hline & Astaxanthin & $\begin{array}{l}\text { Food, nutraceutical, pharmaceuti- } \\
\text { cal; feed additive }\end{array}$ & $\begin{array}{l}\text { Auerswald and Gäde (2008); Denise and } \\
\text { Jason (2012); Gäde and Auerswald (2005) }\end{array}$ \\
\hline & Proteins & Food and nutraceutical & Nguyen et al. (2016); Oviedo et al. (1982) \\
\hline & Flavors and nutrient broth & Crackers, biscuits & Lien (2004) \\
\hline \multirow{4}{*}{$\begin{array}{l}\text { Lobster heads (cephalo- } \\
\text { thorax) }\end{array}$} & Body meat, breast meat, and leg meat & Lobster paste, canned products & Ross (1927) \\
\hline & Lobster meat & Gourmet food products & Meyers and Machada (1978) \\
\hline & & Feed additive & Daniel (2008) \\
\hline & Lobster protein hydrolysate & $\begin{array}{l}\text { Flavor enhancer, protein } \\
\text { supplement }\end{array}$ & Vieira et al. (1995) \\
\hline Lobster roes & Raw roe & Lobster paste, canned products & Ross (1927) \\
\hline \multirow{2}{*}{$\begin{array}{l}\text { Lobster livers (hepato- } \\
\text { pancreas) }\end{array}$} & Raw liver & Lobster paste, canned product & Ross (1927) \\
\hline & $\omega-3$ rich lipids & Lobster oils, infused oils & Nguyen et al. (2015); Tsvetnenko et al. (1996) \\
\hline \multirow{3}{*}{$\begin{array}{l}\text { Lobster blood (hemo- } \\
\text { lymph) }\end{array}$} & Phenol oxidase & Anti-microbial proteins & Fredrick and Ravichandran (2012) \\
\hline & Crustin & Anti-microbial proteins & $\begin{array}{l}\text { Battison et al. (2008); Pisuttharachai et al. } \\
\text { (2009) }\end{array}$ \\
\hline & Bioactive fragment & $\begin{array}{l}\text { Pharmaceutical and/or cosmetic } \\
\text { treatment of viral and other } \\
\text { neoplastic or pre-neoplastic } \\
\text { mammalian tissue lesions }\end{array}$ & Bayer (2015) \\
\hline
\end{tabular}


(Panulirus spp.) has been utilized for lobster flavor production by enzymatic hydrolysis of lobster head meats (Vieira et al. 1995). Hydrolyzed lobster protein could be used as flavor enhancers for various formulated food products. The key aromatic components derived from cooked tail meat of American lobster (Homarus americanus) was investigated by Lee et al. (2001). In this study, 3-methylbutanal, 2,3-butanedione, (Z)-heptenal, 3-(methylthio)propanal, 1-octadien-3-one, and (E,Z)-2,6-nonadienal were identified as dominant aroma components of cooked American lobster tail meat with high odor intensities. By this reason, flavorants extracted from lobster shells by either frying with edible oils or cooking for nutrient extraction were used for production of infused lobster oil and lobster cracker biscuit (Lien 2004). Due to possessing several functional properties that are favorable for use in food industry, LSP has also been characterized and trialed for various applications including food-functional ingredients or as protein supplements (Nguyen et al. 2016; Oviedo et al. 1982), enhancing water-binding or reducing lipidemic effects of meat protein (Nguyen et al. 2016), emulsifier (He et al. 2016).

\section{Lobsters chitin, chitosan, and their derivatives as natural biopolymers for multiple applications}

In recent decades, a greater knowledge of chitin chemistry accompanied by the increased availability of crustacean shells as by-products of the crustacean-processing industry have led to significant development and wide applications of chitin and its derivatives produced by several pathways (Fig. 5). In particular, derivatives from chitin such as chitosan and COS are highly valued compounds as they have more than 200 commercial applications (Kaur and Dhillon 2013; Muzzarelli 1989; Sandford 1989; Synowiecki and Al-Khateeb 1997). In addition, the biopolymers generated from marine crustaceans, lobster chitin, chitosan, and their derivatives have been used in multitude of industries including water treatment, agriculture, food production, pharmaceuticals, and biomedicine (Table 4).

\section{Water treatment}

One of common applications of chitin and its derivatives is for the treatment of water. Chitin and chitosan with their high absorbance, chelating, and affinity properties have been used as coagulation agents, chelating polymers, or bio-absorbents in water treatment for decades. In particular, chitin and chitosan prepared from lobster have shown high affinity for metal chelating. Peniche-Covas et al. (1992) reported lobster chitosan could effectively remove mercuric ions from solutions. Lobster chitosan was later used successfully for separation of heavy metals $(\mathrm{Cu}, \mathrm{Hg}$ ) (Gustavo et al. 2005). The heavy metal removal efficiency of lobster chitosan was comparable to that of commercial resin. Lobster chitin/chitosan has been used for the removal of reactive dyes (vinyl sulfone and chlorotriazine) from aqueous solution (Juang et al. 1997). Lobster chitin/chitosan produced from this study had significantly high adsorption capacity of reactive dyes $(50-500 \mathrm{mg} / \mathrm{L})$ compared with a conventional absorbent (activated carbon). The result of this study has been recently amplified by a study of

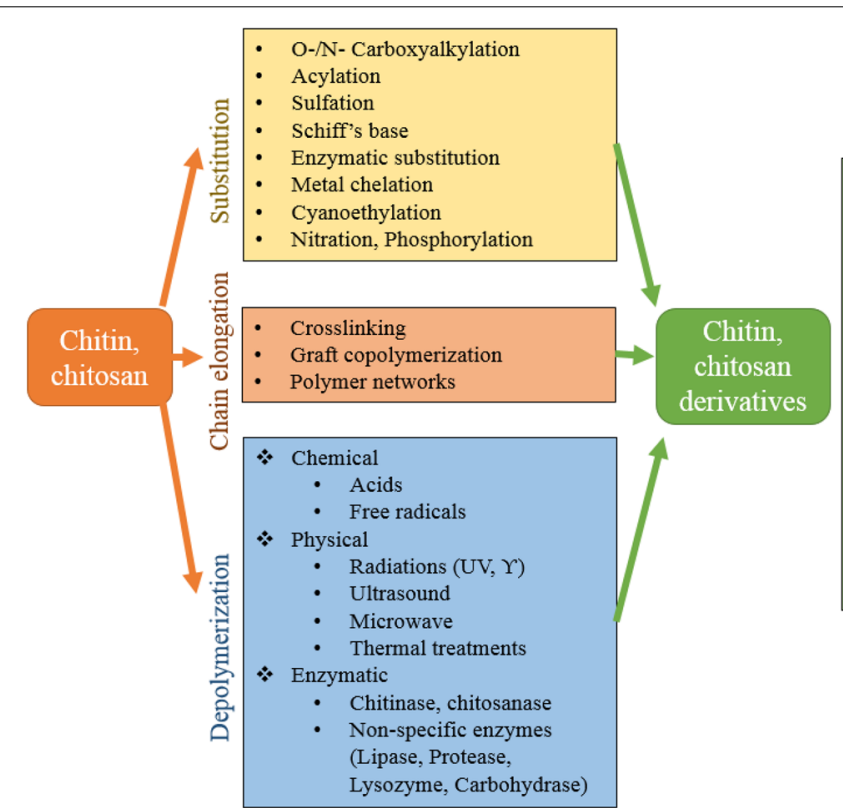

- Chitosan with high DD, Quaternized chitosan, Highly cationic derivatives: improving cationic properties

- N-alkyl, acyl-chitosan, Peg-Chitosan, Hydroxyalkyl-chitosan, Carboxyalkyl-chitosan: improve water solubility

- Carboxyalkyl chitosan, Phosphonic-chitosan, Sulfonic-chitosan: amphoteric polyelectrolytes

- Sugar modified chitosan: cell targeting Azidated-chitosan: photosensible derivatives N-alkyl chitosan, Acyl-chitosan, Graft derivatives, Crown-ether derivatives, Cyclodextrin derivatives: Amphiphilic derivatives

- Low molecular weight chitosan, Chitosan oligomers: low viscosity, better solubility:

Fig. 5 The methods used to produce chitin/chitosan derivatives with the improved functional properties 
Table 4 Applications of lobster chitin, chitosan, and their derivatives

\begin{tabular}{|c|c|c|}
\hline Industry & Applications & References \\
\hline \multirow[t]{4}{*}{ Water treatment } & Removal of mercuric ion & Peniche-Covas et al. (1992) \\
\hline & Removal of reactive dyes from aqueous solution & Juang et al. $(1996,1997)$ \\
\hline & Removal of heavy metals $(\mathrm{Cu}, \mathrm{Hg})$ & Gustavo et al. (2005) \\
\hline & Dye absorbents for treatment of industrial effluent & Pathiraja (2014) \\
\hline \multirow[t]{8}{*}{ Agriculture } & Seedling growth and antimycorrhizal in tomato crop & Iglesias et al. (1994) \\
\hline & Fungicides on plant fungal diseases & Pombo (1995) \\
\hline & Amending media and seeds for inhibition of pathogen fungus growth & Borges et al. (2000) \\
\hline & Inducing systemic resistance agents in tobacco plants & Falcón et al. (2002) \\
\hline & Elicitors of plants defense reactions & Cabrera and Van Cutsem (2005) \\
\hline & Plant growth regulators & Hipulan (2005) \\
\hline & Inducing defensive agents & Cabrera et al. (2010); Falcón Rodríguez et al. (2010) \\
\hline & Plant protection & Ilangumaran (2014) \\
\hline \multirow[t]{5}{*}{ Food } & Organic polymer flocculants & Defang et al. (2001) \\
\hline & Edible or biodegradable films & Casariego et al. $(2008,2009)$ \\
\hline & Biodegradable packages & Hudson et al. (2015) \\
\hline & Fiber and nutrient supplement & Harikrishnan et al. (2012) \\
\hline & Antioxidants, antimicrobials & Garcıa et al. (2015); Sayari et al. (2016) \\
\hline \multirow[t]{7}{*}{ Pharmaceuticals } & Direct compression excipients for pharmaceutical application & Mir et al. (2008) \\
\hline & Co-diluent in direct compression of tablets & Mir et al. (2010) \\
\hline & Water-soluble lobster chitosan salt as materials for drug carriers & Cervera et al. (2011) \\
\hline & Targeted drug delivery film & Bamgbose et al. (2012) \\
\hline & Bio-mouth spray for anti-halitosis & Safitri et al. (2014) \\
\hline & The stability and safety of lobster chitosan salts & De la Paz et al. (2015); Lagarto et al. (2015) \\
\hline & Natural additive for pharmaceuticals & Sayari et al. (2016) \\
\hline \multirow[t]{3}{*}{ Biomedicine } & Immobilization of multi-enzyme extract & Osinga et al. (1999) \\
\hline & Novel hybrid biomaterials for medical application & Malho et al. (2014) \\
\hline & Biomimetic functional materials or epithelial treatment & Qi (2015); Da Silveira et al. (2013) \\
\hline
\end{tabular}

Pathiraja (2014) where lobster chitin was used as dye absorbents for effective treatment of industrial effluent.

\section{Agriculture}

Chitin and its derivatives have been shown to have profound beneficial effects when used for agriculture applications. For example, these polymers stimulate plant growth and improve crop yields (Badawy and Rabea 2011; Deepmala et al. 2014; El Hadrami et al. 2010; Sharp 2013). In addition, when applied to crops, they exhibit toxicity to plant pests and pathogens, induce plant defenses, have high anti-fungal activity, and stimulate the growth and activity of beneficial microbes (Pombo 1995; Sharp 2013). Based on these findings, cheap sources rich in chitin such as lobster shells have been trialed as fungicides, biocides, and bio-stimulants.

Other biological effects induced by lobster chitosan when applied to plant seeds were reported by Borges et al. (2000). Those authors used chitosan prepared from lobster chitin to amend agar and coat tomato seeds together with menadione sodium bisulfite for inhibition of pathogenic fungus and disease development on tomato seeds. The results showed that lobster chitosan significantly inhibited the fungal growth and diminished disease occurrence in the roots from seeds, which had been treated. In another study, lobster chitin was shown to have positive effects on seedling growth and mycorrhizal infection of tomato crop (Iglesias et al. 1994). Furthermore, chitin extracted from Cuban lobster shells has been shown to have biological functions. Researchers at the University of Havana prepared chitosan from lobster chitin to coat tomato seeds as well as encapsulate somatic embryos to produce artificial seeds for accelerating yields. Under laboratory conditions, the coated seeds exhibited considerably higher rates of germination and growth compared with the noncoated seeds. From this study, it was concluded that the lobstershell-derived chitosan served as a biological stimulant yielding better seed germination, increased plant height, enhanced stem thickness, and dry biomass yield (Hareyan 2007). 
Chitin, chitosan, and COS recovered from lobster shells have also been studied for their biocide and biostimulant activities for agricultural applications. A study carried out by Falcón et al. (2002) investigated the use of lobster chitosan and chitosan oligomers for crop protection. Both lobster chitosan and its enzymatic hydrolysate exhibited high pathogen-resistant activity against Phytophthora parasitica on tobacco plants at low concentrations ranging from $5-500 \mathrm{mg} / \mathrm{L}$. With this success, the study was extended by preparing various chitosan and chitosanoligomers from Cuban lobster chitin. Both lobster chitosan and its derivatives were tested for antimicrobial activity (versus fungus and oomycetes) and their ability to induce defensive and protective responses in tobacco and rice plants. Some of the lobster chitosan derivatives were found to be active protectants against infection for both cultivars at field scale (Falcón Rodríguez et al. 2010).

In another study, Peters et al. (2006) used raw lobster shells and compost as a soil amendment to supply nutrients for plants and as a biological control method for soilborne fungi pathogenic to potatoes. The results showed that lobster shells served as a nutrient source for plant growth, enhanced beneficial soil microbial communities, suppressed soil-borne diseases, and was an organic production process. Following this success, Ilangumaran (2014) studied isolation of soil microbes for bioconversion of lobster shells into chitin and chitin-oligomers for plant disease management. The extracted bioproducts showed significant induction of disease resistance in Arabidopsis confirming the findings in previous studies.

\section{Food industry}

The use of chitin, chitosan, and their derivatives in food industry has aroused a great interest in recent years because these biopolymers possess several interesting biological activities and functional properties. Chitin recovered from Spiny lobster shells was used to produce low molecular weight chitosan for food applications using gamma irradiation. Lobster chitosan produced from this irradiation process had high antioxidant activity and was proposed to be utilized as a food preservative (Garcia et al. 2015). Apart from that, chitosan originated from Norway lobster shells had excellent antimicrobial activity against several food-poisoning bacteria and fungus (Sayari et al. 2016). This makes lobster chitosan has a great potential to be used for preservation of foods from microbial deterioration. To recover soluble proteins from food-processing processes, several compounds could be used, but chitosan and chitosan complexes have a great potential (Lu et al. 2011; Wibowo et al. 2007); besides, chitosan prepared from lobster showed promising results for recovery of solids in food-processing plants (Defang et al. 2001). Moreover, chitin and chitosan could be used for producing functional biomaterials (membranes, films, and packages) used for applications in the food industry (e.g., processing, packaging, or storage). Lobster chitosan films were used as the film matrix in combination with clay micro/nanoparticles for the preparation of chitosan/ clay films (Casariego et al. 2008, 2009). With its significant improvements in physical properties (water solubility, water vapor, oxygen and carbon dioxide permeability, and optical, mechanical, and thermal properties), the lobster chitosan/clay film was proposed for use in coating in order to extend the shelf life of food products (Casariego et al. 2008, 2009). Apart from retarding moisture migration and the loss of volatile compounds, reducing the respiration rate, and delaying changes in textural properties, another advantage of chitosan films is that it is biodegradable. Thus, chitosan films are environmentally friendly alternatives to synthetic, nonbiodegradable films, which may be further modified to create biodegradable food packages (Hudson et al. 2015).

\section{Pharmaceuticals and biomedicine}

Recently, the applications of chitin, chitosan, and their derivatives in pharmaceuticals and biomedicines have received more attention not only because they are biocompatible, biodegradable, and nontoxic (Jeon and Kim 2000), but also because they exhibit several biological and physiological characteristics with known medical benefits. For example, these polymers and their derivatives are antioxidant, antimicrobial, anticancer, immune-stimulant, hypocholesterolemic, hypoglycemic, angiotensinI-converting enzyme (ACE) inhibitors, and anticoagulant (Sayari et al. 2016; Wijesekara and Kim 2010).

Apart from the above, chitin and chitin derivatives also possess several physical properties that are favorable for their applications in pharmaceutical and biomedical sectors. Chitin and chitosan prepared from lobster were studied on their deformation and compaction properties for use as pharmaceutical direct compression excipients (Mir et al. 2008). In comparison with other established direct compression excipients (microcrystalline cellulose), lobster chitin/chitosan performed better at both tendencies of plastic deformation and compression behavior. This result indicates that lobster chitin and chitosan have a potential use as co-excipients for direct compression applications.

The most commonly used chitosan derivatives used in drug delivery are the water-soluble lobster chitosan acid salts (Cervera et al. 2011). Lobster chitosan salts prepared by spray-drying have a higher tendency toward sphericity, which are good excipients for pharmaceutical applications. Moreover, lobster chitosan acid salts maintain their physical, chemical, and microbiological characteristics for a period of 12 months when stored correctly at 
room temperature in a dry place (De la Paz et al. 2015). Apart from being stable for extended periods (1 year), the toxicity levels of lobster chitosan acid salts are negligible. This was indicated by a study investigating the singleand repeated-dose toxicity of chitosan and its salts (lactate and acetate) on rats. At oral doses of $2000 \mathrm{mg} / \mathrm{kg}$, no fatalities or changes in the general behavior of the rats in both the acute- and repeated-dose toxicity studies were observed (Lagarto et al. 2015). This led us to a conclusion that chitosan obtained from lobster shells may be safe for use in the pharmaceutical industry.

The welling potential of lobster chitosan film in various solvents was determined for use as targeted drug delivery or drug film (Bamgbose et al. 2012). Since it can generate a membrane with structure porous and stability in several organic solvents, lobster chitosan film could be incorporated in devices for development of targeted drug delivery. Recently, novel hybrid biomaterials for medical application was also prepared from lobster chitosan (Malho et al. 2014). A bifunctional protein was successfully attached to lobster chitin to generate biosynthetic materials with advanced functional properties. Bio-inspired chitin/protein nanocomposites were developed using lobster chitin nanofibers and recombinant chitin-binding resilin (Qi 2015). Furthermore, chitosan nanoparticles with its antioxidant, antimicrobes in combination with high absorption have been used as pharmaceutical ingredients. Recently, Safitri et al. (2014) reported chitosan nanoparticles produced from lobster had positive results in prevention and treatment of halitosis. Based on these findings, the lobster chitosan nanoparticles were used as an active ingredient in a antihalitosis bio-mouth spray. Ongoing advances such as these could considerably expand the use of lobster chitin nanofiber-based composites and functional materials.

\section{Lobster lipids: as source of nutraceuticals, pharmaceuticals, and flavorants}

Although lipids have often been condemned, the use of lipid and its products has drawn a dramatic interest in recent years due to findings related to their effects on human health. Apart from enhancing flavor, texture, and mouthfeel to foods, lipids also provide essential fatty acids [eicosapentaenoic acid (EPA), docosahexaenoic acid (DHA), arachidonic acid (AA), and $\gamma$-linolenic acid], fat-soluble vitamins (A, D, E, K), and other minor components (phospholipids, tocopherols, tocotrienols, carotenoids, sterols, and phenolic compounds) (Rizliya and Mendis 2014; Shahidi 2006). Particularly, the roles of carotenoids, EPA, and/or DHA in heart health, mental health, brain, and retina development, have been well documented (Alabdulkarim et al. 2012; Guerin et al. 2003; Swanson et al. 2012; Yamashita 2013), and such lipid constituents have been regconized as nutraceuticals and pharmaceuticals for improving human health. By this reason, fish oils have been used for enriching DHA and EPA of many food products such as powder milk formulate, salad oil, fruit beverage, vegetable juice (Kolanowski and Berger 1999), dairy products (Kolanowski and Weißbrodt 2007), soft goat cheese (Hughes et al. 2012), or cookies (Jeyakumari et al. 2016). Lobster oils have a potential use as a source of natural $\omega-3$ fatty acids for many fortified products since they have been demonstrated to contain PUFAs and $\omega-3$ fatty acids as high as that of fish oil (menhaden) or krill oils (Albalat et al. 2016; Tsvetnenko et al. 1996). Moreover, higher bioavailability of fatty acids derived from crustacean oils compared to those of fish oils (Köhler et al. 2015) together with the antioxidant superior of crustacean oils provided by carotenoids make them ideal for application as a novel and beneficial food ingredient (Tetens 2009) or as oil supplement (Köhler et al. 2015). With a significant richness in astaxanthin, PUFAs, and $\omega-3$ fatty acids, lobster oil was suggested for use as a dietary supplement (Nguyen 2017) since oils produced from fish livers are often considered as an important source of vitamins A and D with several therapeutic properties (Gunstone 2006; Rizliya and Mendis 2014). In addition, lobster liver oil contains very strong specific flavors, which combined with the unique and inherent ability of oils for absorbing and preserving flavors, would be a promising application for flavor industry. For this reason, lobster lipids were investigated for production of infused lobster oil, salt plated with lobster flavors, and lobster seasoning, and they obtained promising results (Nguyen 2017).

\section{Astaxanthin as a powerful antioxidant}

Oxidative molecules or free radicals such as hydroxyls, peroxides, and reactive oxygen species generated during normal aerobic metabolism are necessary for sustaining life processes. However, under certain conditions or periods of exposure such as physiological stress, air pollution, smoking, chemical inhalation, or exposure to UV light, the increased production of these free radicals can be detrimental. This threat arises due to the highly reactive nature of free radicals with essential cellular components such as proteins, lipids, carbohydrates, and DNA (Di Mascio et al. 1991). As a result of oxidative damage through a chain reaction known as oxidative stress, proteins and lipids are oxidized, while DNA is severely damaged. It has been suggested that diseases such as macular degeneration, retinopathy, carcinogenesis, arteriosclerosis, and Alzheimer may be induced by such damages (Maher 2000).

The human body controls and reduces oxidation by self-producing enzymatic antioxidants including catalase, 
peroxidase, super oxide dismutase, and other antioxidant activity molecules. However, the levels of these compounds in many cases are not sufficient to protect the body against oxidative stress, and an additional supplement of water-soluble antioxidants (vitamin C) and lipophilic antioxidants (vitamin E, carotenoids: beta-carotene and astaxanthin) are required. The use of astaxanthin as an antioxidant has been receiving significant attention because it possesses superior antioxidant activity. Antioxidant activity of astaxanthin was found to be 10 times higher than that of zeaxanthin, lutein, canthaxanthin, and $\beta$-caroten, and 100 times higher compared with vitamin E (Miki 1991). With its superior antioxidant activity, astaxanthin has been used as a natural antioxidant in edible oil (Rao et al. 2007), nutraceuticals (Guerin et al. 2003), and cosmetics (Tominaga et al. 2012). Particularly, astaxanthin has shown great potential for promoting human health and in the prevention/treatment of various diseases (Table 5). Its efficiency has been proven in over 65 clinical studies and featured in over 300 peer-reviewed publications (Yamashita 2013). It should be noted that other carotenoids can act as a prooxidant under specific conditions such as high oxygen and partial pressure, while there is currently no information available regarding astaxanthin. Therefore, astaxanthin is considered as a high-value product due to its being increasingly marketed as a functional food ingredient with prices ranging between 3000 and $\$ 12,000$ per $\mathrm{kg}$ (Lordan et al. 2011).

\section{Industrially applicable techniques for efficient recovery of functional and bioactive nutraceuticals from lobster processing by-products}

Extraction of functional and nutritional proteins by isoelectric solubilization/precipitation and ultrasound-assisted extraction

Commercial lobster processing for fresh lobster meat, picked lobster meat, or canned lobster generates large amounts of lobster by-products containing residual meat, which is not frequently recovered by hand, or using mechanical equipment. This underutilization of the lobster results in a waste with highly valuable protein, which must be disposed of accordingly, frequently at a cost to the producers. Several possibly suitable techniques for the recovery of proteins from crustacean-, fish-, or meatprocessing by-products have been considered. One of the most conventional methods used to transform fishery by-products into a marketable and consumer-friendly

Table 5 Several beneficial effects of astaxanthin on promoting human health

\begin{tabular}{|c|c|c|}
\hline Human health & Health benefits & References \\
\hline $\begin{array}{l}\text { Neurovascular protec- } \\
\text { tion }\end{array}$ & $\begin{array}{l}\text { Decreases oxidation of red blood cells; decreases the } \\
\text { chances of ischemic stroke; and improves memory and } \\
\text { learning }\end{array}$ & Yook et al. (2015); Zhang et al. (2014a, b) \\
\hline Eye fatigue relief & $\begin{array}{l}\text { Reduces eye fatigue relieve in subjects suffering from visual } \\
\text { display syndrome }\end{array}$ & $\begin{array}{l}\text { Kajita et al. (2009); Kidd (2011); Nagaki et al. (2006); Serrano } \\
\text { and Narducci (2014); Seya et al. (2009) }\end{array}$ \\
\hline $\begin{array}{l}\text { Immune system } \\
\text { booster }\end{array}$ & $\begin{array}{l}\text { Has an immunomodulating effect, strong immune system } \\
\text { stimulator, anti-tumor, very effective for autoimmune } \\
\text { conditions such as rheumatoid arthritis }\end{array}$ & $\begin{array}{l}\text { Chew et al. (2010); Chew and Park (2004); Jyonouchi et al. } \\
\text { (1995); Nir and Spiller (2002); Park et al. (2010) }\end{array}$ \\
\hline Cardiovascular health & $\begin{array}{l}\text { Improves blood lipid profiles, decreases blood pressure, } \\
\text { offers protection from hypertension and stroke, reduces } \\
\text { the consequences of a heart attack and vascular inflam- } \\
\text { mation, reduces the area of infarction and the damage, } \\
\text { reduces the area of infarction and the damage }\end{array}$ & $\begin{array}{l}\text { Fassett and Coombes (2012); Fassett and Coombes (2011); } \\
\text { Gross and Lockwood (2005); Guerin et al. (2003); Hussein } \\
\text { et al. (2006); Hussein et al. (2005); Iwamoto et al. (2000); } \\
\text { Miyawaki et al. (2008) }\end{array}$ \\
\hline $\begin{array}{l}\text { Liver health and meta- } \\
\text { bolic syndrome }\end{array}$ & $\begin{array}{l}\text { Improves blood lipids and increases adiponectin, prevents } \\
\text { fatty liver disease, reduces the risk of atherosclerotic } \\
\text { plaque, inhibits progression of fatty liver disease, restores } \\
\text { insulin-glucose balance, increases fat burning, and } \\
\text { decreases inflammatory markers }\end{array}$ & $\begin{array}{l}\text { Kindlund and BioReal (2011); Kishimoto et al. (2016); Shen et al. } \\
\text { (2014); Yilmaz et al. (2015) }\end{array}$ \\
\hline Diabetes and Kidneys & $\begin{array}{l}\text { Reduces glucose toxicity and kidney inflammation; improves } \\
\text { pancreatic function, insulin resistance, and insulin sensitiv- } \\
\text { ity }\end{array}$ & $\begin{array}{l}\text { Naito et al. (2004); Ni et al. (2015); Savini et al. (2013); Uchiyama } \\
\text { et al. (2002) }\end{array}$ \\
\hline Fertility & Improves sperm parameters and fertility & Comhaire et al. (2005); Donà et al. (2013); Mina et al. (2014) \\
\hline Muscle resilience & $\begin{array}{l}\text { Enhances power output, endurance, and recovery after exer- } \\
\text { cise; prevents muscle damage and muscle atrophy }\end{array}$ & $\begin{array}{l}\text { Earnest et al. (2011); Malmstena and Lignellb (2008); Yamashita } \\
\text { (2011) }\end{array}$ \\
\hline Capillary circulation & $\begin{array}{l}\text { Improves blood flow and capillary integrity; reduces blood } \\
\text { cell oxidation and risk of thrombosis }\end{array}$ & Kanazashi et al. (2013) \\
\hline Anti-aging (skin cells) & $\begin{array}{l}\text { Prevents UV-induced wrinkle formation, skin sagging, and } \\
\text { age-spots; improves skin elasticity and skin dryness }\end{array}$ & Seki et al. (2001); Tominaga et al. (2012); Yamashita (2005) \\
\hline
\end{tabular}


products is the use of endogenous or added proteolytic enzymes (Tong-Xun and Mou-Ming 2010; Venugopal and Shahidi 1995). However, the slow rate of hydrolysis, generation of short-chain peptides, loss of functionality of the native proteins, and the absence of homogeneous hydrolysates are other major limitations of this process (Kristinsson and Rasco 2000). Moreover, enzymes used often require an inactivation step and thus cannot be recycled for subsequent reactions leading to the rise of processing costs (Kristinsson and Rasco 2000). In addition, low yield, taste defects, and the overall economic feasibility are still major issues for using enzymatic hydrolysis on industrial scales. Other approaches, which have been explored, include the use of chemicals. Using acidic or alkaline solutions for degrading proteins into peptides of varying sizes is a nonselective and rapid method. However, the severe conditions $(\mathrm{HCl} 6 \mathrm{~N}$, $118{ }^{\circ} \mathrm{C}, 18 \mathrm{~h}$, or $\mathrm{pH} 12.5,95^{\circ} \mathrm{C}, 20 \mathrm{~min}$ ) used in chemical hydrolysis can have negative consequences such as racemization, bitter taste, reduced nutritional quality, and poor functionality, resulting in products of lower value, i.e., fertilizer (Chobert et al. 1996).

A more promising technique is isoelectric solubilization and precipitation (ISP). The shifting in $\mathrm{pH}$ of the solutions used during this processing induces solubility of residual proteins while simultaneously separating of lipids and the inedible parts such as shells, membranes, bones, scales, and skin, not intended for human consumption (Gehring et al. 2011). Apart from its generating high yield of protein recovery, this process also produces high-quality proteins, which still maintain their functional properties and nutritional value (Chen et al. 2007b; Gigliotti et al. 2008; Nolsoe and Undeland 2009; Taskaya et al. 2009a; Taskaya et al. 2009b). Since the ISP process is simple and quick, it has been used for the recovery of fish proteins at both laboratory and pilot scales using batch mode (Choi and Park 2002; Kim et al. 2003; Kristinsson and Hultin 2003; Mireles Dewitt et al. 2002; Undeland et al. 2002). Furthermore, the presence of dioxin and polychlorinated biphenyls (PCBs), one of the most predominant bio-toxic compounds in fish protein, has been found to be reduced significantly in the ISP-recovered proteins (Marmon et al. 2009). When applied to other biological waste materials such as beef-processing by-products (Chen et al. 2007a; Mireles Dewitt et al. 2002) or chickenprocessing by-products (Tahergorabi et al. 2011; Tahergorabi et al. 2012), high yields of protein recovery were still achieved. With its significant advantages over conventional methods, the ISP process could have a great potential for application on protein recovery from LPBs.

Recently, ultrasound-based extractions have been shown to be an effective technique for improving the rates of various extraction processes (Lebovka et al. 2011;
Majid et al. 2015; Vilkhu et al. 2008). Ultrasound processing disrupts cells and creates microcavities in the tissue, which enhances the surface area and thus in the penetration of the solvent into the material, mass transfer, and improves protein release. The use of ultrasound in protein extraction from fish, meat, and beef by-products resulted in higher extraction yields with reduced processing time and solvent consumption compared with the use of ISP alone (Chemat and Khan 2011; Saleem et al. 2015; Vardanega et al. 2014; Vilkhu et al. 2008). Therefore, recovery of protein by ultrasound-assisted extraction has been scaled up to an industrial level due to their high economic feasibility (Álvarez and Tiwari 2015; Tu et al. 2015).

\section{Supercritical fluid extraction for recovery of rich- $\omega-3$ lipids and astaxanthin}

Solvent extraction is the most common method for lipid or astaxanthin extraction (Sindhu and Sherief 2011; Tsvetnenko et al. 1996). In this method, organic solvents including acetone, ethyl acetate, hexane, isopropanol, methanol, methyl ethyl ketone, ethanol, dichloromethane, dimethyl sulfoxide, or chloroform may be used for the extraction. Although some of these solvents can be used to extract lipids for food applications, others such as dichloromethane, dimethyl sulfoxide, and chloroform cannot be used due to their toxicity (FDA 2010). Regardless of the solvent used, there is increasing public awareness of the hazards related to the use of any organic solvents in the extraction of compounds for food or medical applications due to the possibility of solvent contamination in the final extracts. Apart from this, high demands for natural astaxanthin and bioactive lipid components such as $\omega-3$ fatty acids, physterols, tocopherols, and tocotrineols have stimulated the search for green and sustainable extraction methods (Delgado Vargas and Paredes-Lopez 2003). One such approach that is being considered is the use of supercritical fluid extraction techniques.

In recent years, supercritical fluid extraction (SFE) has become an important technology for extracting high-quality lipids from fishery-processing by-products (Letisse et al. 2006; Rubio-Rodríguez et al. 2008). Furthermore, it is an effective separation technique in the production of nutraceutical supplements and functional foods (Parajó et al. 2008; Reverchon and De Marco 2006). The operational conditions of SFE are also favorable from an environmental and industrial processing viewpoint. SFE can extract bioactive nutraceuticals at moderate temperatures in a non-oxygen environment with very low lipid oxidation, selectively extracts low polar lipid compounds, and does not co-extract polar impurities such as some organic derivatives containing heavy metals (Rubio-Rodríguez et al. 2012). 
Supercritical carbon dioxide $\left(\mathrm{SC}-\mathrm{CO}_{2}\right)$ extraction is presently being evaluated as a promising technology compared with conventional methods (López-Cervantes et al. 2006) due to its ability to extract the heat-sensitive, easily oxidized compounds (PUFAs, $\omega-3$ fatty acids, and astaxanthin) without the use of toxic solvents. Moreover, $\mathrm{CO}_{2}$ is a generally recognized as safe (GRAS), relatively cheap, and easy to evaporate from the matrix and extracts (Mercadante 2008; Reverchon and De Marco 2006; Sahena et al. 2009). The high extraction yields achieved using this technique is attributable to the high diffusivity and solubility but low viscosity of $\mathrm{SC}-\mathrm{CO}_{2}$. In contrast to the products extracted from the conventional methods, the $\mathrm{SC}-\mathrm{CO}_{2}$ extracts are rich in nutraceuticals with high purity. $\mathrm{SC}-\mathrm{CO}_{2}$ have been used to extract lipids and carotenoids from vegetables (Filho et al. 2008; Hardardottir and Kinsella 1988; Mendes et al. 1995; Silva et al. 2008) and animal matrices (Froning et al. 1990; Hardardottir and Kinsella 1988; Letisse et al. 2006; Tanaka and Ohkubo, 2003). The $\mathrm{SC}-\mathrm{CO}_{2}$ extraction technique has also been studied for extraction of lipids and astaxanthin from crustacean-processing waste such as shrimp by-products (Charest et al. 2001; Felix-Valenzuela et al. 2001; Kamaguchi et al. 1986; Lopez et al. 2004). Recently, $\omega$-3-rich lipids have been recovered with high yield (94\%) from Rock lobster livers by $\mathrm{SC}-\mathrm{CO}_{2}$ extraction (Nguyen et al. 2015).

\section{Microwave-intensified production of chitin and chitin derivatives}

Chitin is found in lobster shells and is closely associated with proteins, minerals, and pigments, which need to be completely removed and separated from chitin during the extraction process. Although conventional methods removes nearly all these compounds from the shells, the use of strong chemicals and high temperatures during the process can cause deacetylation and depolymerisation leading to inconsistent physical properties of the extracted chitin (Jung et al. 2007; Kjartansson et al. 2006; Percot et al. 2003). In addition, under these harsh conditions, undesirable secondary reactions between amino acids and the alkaline medium as well as racemization occur rending the proteins and minerals unusable (Synowiecki and $\mathrm{Al}$-Khateeb 2003). Moreover, the conventional method requires large volumes of water for washing steps, generating a huge amount of waste water (Wang and Chio 1998). To circumvent these issues, various biological processes have been employed for the production of chitin from crustacean shells such as fermentation or using commercially available enzymes (Giyose et al. 2010; Jung et al. 2007; Manni et al. 2010; Oh et al. 2007; Sini et al. 2007; Sorokulova et al. 2009; Xu et al. 2008). However, these proposed new methods require a longer production time $(8-72 \mathrm{~h})$, while their removal degrees (deproteinization, demineralization) are relatively low.

More recently, microwave has emerged as a promising nonconventional energy source for performing organic synthesis. Heat generated from microwave irradiation accelerates chemical reactions and enhances the rate of enzyme-catalyzed reactions so spectacularly that it cannot be explained by the effect of rapid heating alone (De La Hoz et al. 2005). Apart from thermal effects, microwave irradiation is accompanied with several nonthermal effects such as overheating, hot spots, selective heating, highly polarizing field, and mobility and diffusion. Microwave-assisted extraction has been proven to be an efficient technique for extracting small molecular weight from various biological samples due to its high ability to intensify processes, low usage of extraction chemicals, and shorter extraction time (Teo et al. 2013).

Microwave technology has been used as an environmentally friendly and cost-effective method for chitin production by assisting demineralization of deproteinized shrimp shells with lactic acid (Valdez-Pena et al. 2010). This process produced high yields of chitin with low residual minerals $(0.2 \%)$; thus, demineralization of lobster shells by the microwave process was also optimized for chitin production obtaining promising results such as high degree of demineralization, low residues, and recovery of lobster minerals (Nguyen et al. 2017). The rate and yield of extraction can be further exploited by combining multiple processing approaches such as using microwave technology to increase the rate of enzymatic hydrolysis of lobster shells (Nguyen et al. 2016). Microwave irradiation has also been demonstrated as highly efficient in chemical deacetylation of chitin into chitosan. The degree of deacetylation in chitosan production within 5.5 min of microwave irradiation was as high as it was deacetylated at $121^{\circ} \mathrm{C}, 15 \mathrm{psi}$ for $4 \mathrm{~h}$ (Sahu et al. 2009). To generate chitosan with high solubility or desired functional properties, microwave irradiation has been extensively utilized for the chemical modification of chitosan (Ge and Luo 2005; Huacai et al. 2006; Liu et al. 2004). Particularly, the microwave has been demonstrated as a green and sustainable technology for degradation of chitin (Ajavakom et al. 2012; Roy et al. 2003) and chitosan (Garcia et al. 2015; Li et al. 2012; Petit et al. 2015; Wasikiewicz and Yeates 2013) into low molecular weight chitosan or chito-oligomers in a wide range of applications.

\section{Conclusion}

The global lobster processing industry produces a large amount of by-products with an estimated yield of 50,000 tons, which are currently being underutilized or 
discarded annually costing lobster companies in excess of $\$ 7.5$ million/year for disposal. Finding alternative uses for this waste material could result in more environmentally friendly processes and ultimately result in an economic advantage for the lobster industry. This comprehensive review discusses the global availability of LPBs, the composition of the by-products, and the high-value compounds that may be extracted from them. It also discussed the key areas of applications - that these extracted compounds show potential to be used in-like water treatment, agriculture, food, nutraceutical, pharmaceutical products, and biomedicine. Furthermore, it addresses the limitations to current techniques used for the recovery of these valuable components and suggests emerging innovative techniques (i.e., microwave, ultrasonic, and supercritical fluid extraction) which may be more promising at the industrial scale. Although the potential value of such lobster ingredients is currently being ignored, several recent studies on biorefinery have shown that recovery of these valuable ingredients for value-added products is very promising due to their richness, highly commercial value, and numerous applications. Developing the simplified processes combined with using industrially applicable technologies for economic recovery of these valuable ingredients would be a practical solution for maximizing the utilization of these by-products. In this way, LPBs could be economically turned into a highly profitable source rather than a traditional pollution and costing source.

\section{Abbreviations \\ LPBs: lobster processing by-products; LSP: lobster shell protein; LPH: lobster protein hydrolysate; COS: chito-oligosaccharides; PUFAs: polyunsaturated fatty acids; $\mathrm{SC}_{-} \mathrm{CO}_{2}$ : supercritical carbon dioxide; $\mathrm{SFE}$ : supercritical fluid extraction; EAA: essential amino acids.}

\section{Authors' contributions}

All authors were involved in the drafting and revision of the manuscript. All authors read and approved the final manuscript.

\section{Author details}

${ }^{1}$ Centre for Marine Bioproducts Development, Flinders University, Adelaide, Australia. ${ }^{2}$ Department of Medical Biotechnology, School of Medicine, Flinders University, Adelaide, Australia. ${ }^{3}$ Department of Food Science and Technology, Agricultural and Natural Resources Faculty, An Giang University, Long Xuyen, Vietnam. ${ }^{4}$ Centre for NanoScale Science Technology (CNST), Chemical and Physical Sciences, Flinders University, Adelaide, Australia.

\section{Acknowledgements}

The authors wish to thank the Australian Government for offering Trung Nguyen a Ph.D. scholarship. Thanks to the South Australian Government, the Ferguson Lobster Co. Ltd, and the Premier's Research and Industry FundInnovation Voucher Project (PRIF-IVP) for financial support. Thanks to the Flinders Medical Biotechnology Department and Centre for Marine Bio-products Development for technical supports.

\section{Competing interests}

The authors declare that they have no competing interests.

\section{Availability of data and materials}

All the authors have agreed to provide the data and material for open access.

\section{Funding}

This manuscript is a part of the South Australia Premier's Research and Industry Fund - Innovation Voucher Project (PRIF-IVP37) which was co-funded by the South Australia government and Ferguson Australia Pty Ltd.

\section{Publisher's Note}

Springer Nature remains neutral with regard to jurisdictional claims in published maps and institutional affiliations.

Received: 15 March 2017 Accepted: 16 June 2017

Published online: 22 June 2017

\section{References}

Ajavakom A, Supsvetson S, Somboot A, Sukwattanasinitt M (2012) Products from microwave and ultrasonic wave assisted acid hydrolysis of chitin. Carbohydr Polym 90(1):73-77

Alabdulkarim B, Bakeet ZAN, Arzoo S (2012) Role of some functional lipids in preventing diseases and promoting health. J King Saud Univ-Sci 24(4):319-329

Albalat A, Nadler LE, Foo N, Dick JR, Watts AJ, Philp H, Neil DM, Monroig O (2016) Lipid composition of oil extracted from wasted Norway lobster (Nephrops norvegicus) heads and comparison with oil extracted from Antarctic krill (Euphasia superba). Mar Drugs 14(12):219

Álvarez C, Tiwari BK (2015) Ultrasound assisted extraction of proteins from fish processing by-products. In: institute of food technologist. Chicago, US

Annie T, McCarron P (2006) Lobster market overview. Maine Lobstermen's Association

Auerswald L, Gäde G (2008) Simultaneous extraction of chitin and astaxanthin from waste of lobsters Jasus lalandii, and use of astaxanthin as an aquacultural feed additive. Afr J Mar Sci 30(1):35-44

Badawy MEI, Rabea El (2011) A biopolymer chitosan and its derivatives as promising antimicrobial agents against plant pathogens and their applications in crop protection. Int J Carbohydr Chem 2011:1-29

Bamgbose JT, Bamigbade AA, Adewuyi S, Dare EO, Lasisi AA, Njah AN (2012) Equilibrium swelling and kinetic studies of highly swollen chitosan film. J Chem Chem Eng 6(3):272-283

Barker E, Rossbach M (2013) Western rock lobster fishery_-2013/2014 season. Commercial fisheries production bulletin, vol 48. Department of fisheries, Government of western Australia, pp 1-8

Battison AL, Summerfield R, Patrzykat A (2008) Isolation and characterisation of two antimicrobial peptides from haemocytes of the American lobster Homarus americanus. Fish Shellfish Immunol 25(1):181-187

Bayer RC (2015) Lobster hemolymph as a utility for treatment of mammalian tissue lesions, Google Patents

Borges AA, Borges-Pérez A, Gutiérrez A, Paz-Lago D, Cabrera G, Fernández M, Ramírez MA, Acosta A (2000) Tomato-Fusarium oxysporum interactions: I-chitosan and MSB effectively inhibits fungal growth. Cultivos Trop 21(4):13-16

Cabrera JC, Van Cutsem P (2005) Preparation of chitooligosaccharides with degree of polymerization higher than 6 by acid or enzymatic degradation of chitosan. Biochem Eng J 25(2):165-172

Cabrera J-C, Boland A, Cambier P, Frettinger P, Van Cutsem P (2010) Chitosan oligosaccharides modulate the supramolecular conformation and the biological activity of oligogalacturonides in Arabidopsis. Glycobiology 20(6):775-786

Casariego A, Souza B, Cruz L, Díaz R, Teixeira J, Vicente A (2008) Chitosan coating and films: evaluation of surface, permeation, mechanical and thermal propertiess. Valnatura-A Europe-Latin América post-graduate research network in the valorization of natural resources, institute for biotechnology and bioengineering

Casariego A, Souza B, Cerqueira M, Teixeira J, Cruz L, Díaz R, Vicente A (2009) Chitosan/clay films 'properties as affected by biopolymer and clay micro/nanoparticles' concentrations. Food Hydrocoll 23(7):1895-1902

Cervera MF, Heinämäki J, de la Paz N, López O, Maunu SL, Virtanen T, Hatanpää T, Antikainen O, Nogueira A, Fundora J (2011) Effects of spray drying on physicochemical properties of chitosan acid salts. AAPS Pharm Sci Tech 12(2):637-649 
Charest DJ, Balaban MO, Marshall MA, Cornell JA (2001) Astaxanthin extraction from crawfish shells by supercritical $\mathrm{CO}_{2}$ with ethanol as cosolvent. J Aquat Food Prod Technol 3:81-96

Chemat F, Khan MK (2011) Applications of ultrasound in food technology: processing, preservation and extraction. Ultrason Sonochem 18(4):813-835

Chen YC, Nguyen J, Semmens K, Meamer S, Jaczynski J (2007a) Physicochemical changes in omega-3-enhanced farmed rainbow trout (Oncorhynchus mykiss) muscle during refrigerated storage. Food Chem 104(3):1143-1152

Chen YC, Tou JC, Jaczynski J (2007b) Amino acid, fatty acid and mineral profiles of materials recovered from rainbow trout (Oncorhynchus mykiss) processing by-products using isoelectric solubilization/precipitation. Food Sci 74(2):C527-C535

Chen X, Yang H, Yan N (2016) Shell biorefinery: dream or reality? Chem-A Eur J 22:13402-1342

Chen X, Yang H, Zhong Z, Yan N (2017) Base-catalysed, one-step mechanochemical conversion of chitin and shrimp shells into low molecular weight chitosan. Green Chem 19(12):2783-2792

Chew BP, Park JS (2004) Carotenoid action on the immune response. J Nutr 134(1):257S-261S

Chew B, Park J, Chyun J, Mahoney M, Line L (2010) Astaxanthin decreased oxidative stress and inflammation and enhanced immune response in humans. Nutr Metab 7(1):18

Chobert JM, Briand L, Gueguen J, Popineau Y, Larre C, Haertle T (1996) Recent advances in enzymatic modifications of food proteins for improving their functional properties. Nahr-Food 40(4):177-182

Choi YJ, Park JW (2002) Acid-aided protein recovery from enzyme-rich Pacific whiting. J Food Sci 67:2962-2967

Comhaire F, Garem YE, Mahmoud A, Eertmans F, Schoonjans F (2005) Combined conventional/antioxidant "Astaxanthin" treatment for male infertility: a double blind, randomized trial. Asian J Androl 7(3):257-262

Cousins JA (1997) Primary resource industry waste on Prince Edward Island. The PEI department of fishery and environment

Da Silveira FF, De Souza KL, Nunes Filho A, de Lima Mendes JU, Ladchumananandasivan R (2013) Synthesis and characterization of chitosan used in the treatment of epithelial lesions. In: 22nd international congress of mechanical engineering. Brazil

Daniel M (2008) Evaluating by-products of the Atlantic shellfish industry as alternative feed ingredients for laying hens. Poult Sci 91:2189-2200

Dauphin L (1991) Enhancing value of lobster waste by enzymatic methods. In: food and agriculture chemistry, vol. Master, Mc Gill. Canada

De La Hoz A, Diaz-Ortiz A, Moreno A (2005) Microwaves in organic synthesis. Thermal and non-thermal microwave effects. Chem Soc Rev 34(2):164-178

De la Paz N, García C, Fernández M, García L, Martínez V, López OD, Nogueira A (2015) Stability of spray-dried chitosan salts derived from lobster chitin as a raw material. Ars Pharm 56(4):217-224

Deepmala K, Hemantaranjan A, Bharti S, Nishant Bhanu A (2014) A future perspective in crop protection: chitosan and its oligosaccharides. Adv Plantsand Agric Res 1(1):1-8

Defang Z, Gang Y, Pengyi Z, Zhiwei F (2001) The modified process for preparing natural organic polymer flocculant chitosan. Chin J Environ Sc 22(3):123-125

Delgado Vargas F, Paredes-Lopez (2003) Carotenoids, CRC Press. LLC NW

Denise S, Jason B (2012) Food grade astaxanthin from lobster shell discards. Maine agricultural center

Di Mascio P, Murphy ME, Sies H (1991) Antioxidant defense systems: the role of carotenoids, tocopherols, and thiols. Am J Clin Nutr 53(1):194S-200S

Donà G, Kožuh I, Brunati AM, Andrisani A, Ambrosini G, Bonanni G, Ragazzi E, Armanini D, Clari G, Bordin L (2013) Effect of astaxanthin on human sperm capacitation. Mar Drugs 11(6):1909-1919

Earnest CP, Lupo M, White K, Church T (2011) Effect of astaxanthin on cycling time trial performance. Int J Sports Med 32(11):882-888

El Hadrami A, Adam LR, El Hadrami I, Daayf F (2010) Chitosan in plant protection. Mar Drugs 8(4):968-987

Falcón Rodríguez A, Rodríguez AT, Ramírez MA, Rivero D, Martínez B, Cabrera JC, Costales D, Cruz A, González LG, Jiménez MC (2010) Chitosans as bioactive macromolecules to protect conomically relevant crops from their main pathogens. Biotecnol Apl 27(4):305-309

Falcón A, Ramírez M, Márquez R, Hernández M (2002) Chitosan and its hydrolysate at tobacco-Phytophthora parasitica interaction. Cultivos Trop 23(1):61-66
Fassett RG, Coombes JS (2011) Astaxanthin: a potential therapeutic agent in cardiovascular disease. Mar Drugs 9(3):447-465

Fassett RG, Coombes JS (2012) Astaxanthin in cardiovascular health and disease. Molecules 17(2):2030-2048

FDA (2010) Listing of food additives status, vol 2014, FDA. EUA

Felix-Valenzuela L, Higuera-Ciapara I, Goycoolea FM, Arguelles-Monal W (2001) Supercritical $\mathrm{CO}_{2}$ /ethanol extraction of astaxanthin from blue crab (Callinectes sapidus) shell waste. J Food Eng 24:101-112

Filho GL, De Rosso VV, Meireles MAA, Rosa PTV Oliveira AL, Mercadante AZ, Cabral FA (2008) Supercritical $\mathrm{CO}_{2}$ extraction of carotenoids from pitanga fruits (Eugenia uniflora L.). J Supercrit Fluids 46:33-39

Fredrick WS, Ravichandran S (2012) Hemolymph proteins in marine crustaceans. Asian Pac J Trop Biomed 2(6):496-502

Froning GW, Wheling RL, Cuppett SL, Pierce MM, Niemann L, Seikman DK (1990) Extraction of cholesterol and other lipids from dried egg yolk using supercritical carbon dioxide. J Food Sci 55:95-98

Gäde G, Auerswald L (2005) The West Coast rock lobster Jasus lalandii as a valuable source for chitin and astaxanthin. Afr J Mar Sci 27(1):257-264

Garcia MA, de la Paz N, Castro C, Rodrıguez JL, Rapado M, Zuluaga R, Ganán P. Casariego A (2015) Effect of molecular weight reduction by gamma irradiation on the antioxidant capacity of chitosan from lobster shells. J Radiat Res Appl Sci 8(2):1-11

Gary M (2012) Southern rock lobster strategic plan 2011-2016. Southern Rock Lobster Ltd

Ge H-C, Luo D-K (2005) Preparation of carboxymethyl chitosan in aqueous solution under microwave irradiation. Carbohydr Res 340(7):1351-1356

Gehring CK, Gigliotti JC, Moritz JS, Tou JC, Jaczynski J (2011) Functional and nutritional characteristics of proteins and lipids recovered by isoelectric processing of fish by-products and low value-fish: a review. Food Chem 124:422-431

Gigliotti JC, Jaczynski J, Tou JC (2008) Determination of nutritional value, protein quality and safety of krill protein concentrate isolated using an isoelectric solubilization/precipitation technique. Food Chem 111(1):209-214

Giyose N, Mazomba N, Mabinya L (2010) Evaluation of proteases produced by Erwinia chrysanthemi for the deproteinization of crustacean waste in a chitin production process. Afr J Biotech 9(5):707-710

Gross GJ, Lockwood SF (2005) Acute and chronic administration of disodium disuccinate astaxanthin (CardaxTM) produces marked cardioprotection in dog hearts. Mol Cell Biochem 272(1-2):221-227

Guerin M, Huntley ME, Olaizola M (2003) Haematococcus astaxanthin: applications for human health and nutrition. Trends Biotechnol 21(5):210-216

Gunstone FD (2006) Modifying lipids for use in food, 1 st edn. Woodhead Publishing, Cambridge

Gustavo C, Galo CT, Alexei TVE (2005) Retention capacity of chitosan for copper and mercury ions. J Chil Chem Soc 48(1):1-11

Hamed I, Özogul F, Regenstein JM (2016) Industrial applications of crustacean by-products (chitin,chitosan, and chitooligosaccharides): a review. Trends Food Sci Technol 48:40-50

Hardardottir I, Kinsella JE (1988) Extraction of lipids and cholesterol from fish muscle with supercritical fluid. J Food Sci 53:1656-1661

Hareyan A (2007) Chitin from lobster shell shows great healing, bio-stimulant properties, vol 2014. Universidad de Granada, Cuba

Harikrishnan R, Kim J-S, Balasundaram C, Heo M-S (2012) Dietary supplementation with chitin and chitosan on haematology and innate immune response in Epinephelus bruneus against Philasterides dicentrarchi. Exp Parasitol 131(1):116-124

He S, Nguyen T, Zhang W, Peng S (2016) Protein hydrolysates produced from Rock lobster (Jasus edwardsii) head: emulsifying capacity and food safety. Food Sci Nutr 4(6):869-877

Hipulan JRAM (2005) Chitosan from waste shrimp and lobster shells as plant growth regulator. In: intel Philippines science fair. Cagayan De Oro City

Holmyard N, Franz N (2006) Lobster markets. FAO

Huacai G, Wan P, Dengke L (2006) Graft copolymerization of chitosan with acrylic acid under microwave irradiation and its water absorbency. Carbohydr Polym 66(3):372-378

Hudson R, Glaisher S, Bishop A, Katz JL (2015) From lobster shells to plastic objects: a bioplastics activity. J Chem Educ 92(11):1882-1885

Hughes BH, Brian Perkins L, Calder BL, Skonberg DI (2012) Fish oil fortification of soft goat cheese. J Food Sci 77(2):S128-S133 
Hussein G, Nakamura M, Zhao Q, Iguchi T, Goto H, Sankawa U, Watanabe H (2005) Antihypertensive and neuroprotective effects of astaxanthin in experimental animals. Biol Pharm Bull 28(1):47-52

Hussein G, Goto H, Oda S, Sankawa U, Matsumoto K, Watanabe H (2006) Antihypertensive potential and mechanism of action of astaxanthin: III. Antioxidant and histopathological effects in spontaneously hypertensive rats. Biol Pharm Bull 29(4):684-688

Iglesias R, Gutierrez A, Fernandez F (1994) The influence of chitin from lobster exoskeleton seedling growth and mycorrhizal infection in tomato crop (Lycopersion esculentum mill). Cultivos Trop 15(2):48-49

Ilangumaran G (2014) Microbial degradation of lobster shells to extract chitin derivatives for plant disease management, vol. Master of Science, Dalhousie. Halifax, Nova Scotia

Iwamoto T, Hosoda K, Hirano R, Kurata H, Matsumoto A, Miki W, Kamiyama M, Itakura H, Yamamoto S, Kondo K (2000) Inhibition of low-density lipoprotein oxidation by astaxanthin. J Atheroscler Thromb 7(4):216-222

Jeon YJ, Kim SK (2000) Production of chitooligosaccharides using an ultrafiltration membrane reactor and their antibacteria activity. Carbohydr Polym 41:133-141

Jeyakumari A, Janarthanan G, Chouksey M, Venkateshwarlu G (2016) Effect of fish oil encapsulates incorporation on the physico-chemical and sensory properties of cookies. J Food Sci Technol 53(1):856-863

Juang RS, Tseng RL, Wu FC, Lin SJ (1996) Use of chitin and chitosan in lobster shell wastes for color removal from aqueous solutions. J Environ Sci Health, Part A 31(2):325-338

Juang RS, Tseng RL, Wu FC, Lee SH (1997) Adsorption behavior of reactive dyes from aqueous solutions on chitosan. J Chem Technol Biotechnol 70(4):391-399

Jung W, Jo G, Kuk J, Kim Y, Oh K, Park R (2007) Production of chitin from red crab shell waste by successive fermentation with Lactobacillus paracasei KCTC-3074 and Serratia marcescens FS-3. Carbohydr Polym 68(4):746-750

Jyonouchi H, Sun S, Tomita Y, Gross MD (1995) Astaxanthin, a carotenoid without vitamin A activity, augments antibody response in cultures including T-helper cell clones and suboptimal doses of antigen. J Nutr 125(10):2483-2492

Kajita M, Tsukahara H, Kato M (2009) The effects of a dietary supplement containing astaxanthin on the accommodation function of the eye in middle-aged and older people. Med Consult New Rem 46:89-93

Kamaguchi K, Murakami M, Nakano H, Konosu S, Kokura T, Yamamoto H, Kosaka M, Hata K (1986) Supercritical carbon dioxide extraction of oils from Antartic krill. J Agric Food Chem 34:904-907

Kanazashi M, Okumura Y, Al-Nassan S, Murakami S, Kondo H, Nagatomo F, Fujita N, Ishihara A, Roy R, Fujino H (2013) Protective effects of astaxanthin on capillary regression in atrophied soleus muscle of rats. Acta Physiol 207(2):405-415

Karagozlu MZ, Kim S-K (2015) Anti-cancer effects of chitin and chitosan derivatives. In: Kim S-K (ed) Handbook of anticancer drugs from marine origin. Springer, Heidelberg, pp 413-421

Kaur S, Dhillon GS (2013) Recent trends in biological extraction of chitin from marine shell wastes: a review. Crit Rev Biotechnol 35(1):1-18

Kidd P (2011) Astaxanthin, cell membrane nutrient with diverse clinical benefits and anti-aging potential. Altern Med Rev 16(4):355-364

Kim YS, Park JW, Choi YJ (2003) New approaches for the effective recovery of fish proteins and their physicochemical characteristics. Fish Sci 69(6):1231-1239

Kindlund P, BioReal A (2011) AstaREAL ${ }^{\circledR}$, natural astaxanthin-nature's way to fight the metabolic syndrome. Wellness Foods 1:8-13

Kishimoto Y, Yoshida H, Kondo K (2016) Potential anti-atherosclerotic properties of astaxanthin. Mar Drugs 14(2):1-13

Kjartansson GT, Zivanovic S, Kristbergsson K, Weiss J (2006) Sonication-assisted extraction of chitin from shells of fresh water prawns (Macrobrachium rosenbergii). J Agric Food Chem 54:3317-3323

Knuckey I (2004) Utilisation of seafood processing waste_challenges and opportunites. In: Australian New Zealand soils conference. University of Sydney, Australia

Köhler A, Sarkkinen E, Tapola N, Niskanen T, Bruheim I (2015) Bioavailability of fatty acids from krill oil, krill meal and fish oil in healthy subjects-a randomized, single-dose, cross-over trial. Lipids Health Dis 14(19):1-10

Kolanowski W, Berger S (1999) Possibilities of fish oil application for food products enrichment with omega-3 PUFA. Int J Food Sci Nutr 50(1):39-49
Kolanowski W, Weißbrodt J (2007) Sensory quality of dairy products fortified with fish oil. Int Dairy J 17(10):1248-1253

Kozo F (1997) Extraction of astaxanthin from shell of lobster or shrimp or crab and apparatus therefore. In: Patent J (ed) Japanese patent, vol JP A9301950. Japan

Kristinsson HG, Hultin HO (2003) Changes in conformation and subunit assembly of cod myosin at low and high $\mathrm{pH}$ after subsequent refolding. J Agric Food Chem 51(24):7187-7196

Kristinsson HG, Rasco BA (2000) Fish protein hydrolysates: production, biochemical and functional properties. Crit Rev Food Sci Nutr 40:43-81

Kuhn R, Soerensen N (1938) The coloring matters of the lobster (Astacus gammarus L.). Z Angew Chem 51:465-466

Kumar MNR (2000) A review of chitin and chitosan applications. React Funct Polym 46(1):1-27

Kurita K (2006) Chitin and chitosan: functional biopolymers from marine crustaceans. Mar Biotechnol 8(3):203-226

Lagarto A, Merino N, Valdes O, Dominguez J, Spencer E, de la Paz N, Aparicio G (2015) Safety evaluation of chitosan and chitosan acid salts from Panurilus argus lobster. Int J Biol Macromol 72:1343-1350

Lebovka N, Vorobiev E, Chemat F (2011) Enhancing extraction processes in the food industry. CRC Press, Boca Raton

Lee JE, Peniston Q (1982) Utilization of shellfish waste for chitin and chitosan production. In: Roy EM (ed) Chemistry and biochemistry of marine food products, vol 2. Academic Press, Cambridge, pp 1-5

Lee GH, Suriyaphan O, Cadwallader KR (2001) Aroma components of cooked tail meat of American lobster (Homarus americanus). J Agricand Food Chem 49(9):4324-4332

Letisse M, Rozieres M, Hiol A, Sergent M, Comeau L (2006) Enrichment of EPA and DHA from sardine by supercritical fluid extraction without organic modifier: I. Optimization of extraction conditions. J Supercrit Fluids 38(1):27-36

Li K, Xing R, Liu S, Qin Y, Meng X, Li P (2012) Microwave-assisted degradation of chitosan for a possible use in inhibiting crop pathogenic fungi. Int J Biol Macromol 51(5):767-773

Lien $\sqcup$ (2004) Development of value added foods from low value lobster portions. In: school of agriculture and wine, vol. The bachelor of food technology and management, The University of Adelaide. Adelaide

Liu L, Li Y, Li Y, Fang Y-E (2004) Rapid N-phthaloylation of chitosan by microwave irradiation. Carbohydr Polym 57(1):97-100

Lopez M, Arce L, Garrido J, Rios A, Valcarcel M (2004) Selective extraction of astaxanthin from crustaceans by use of supercritical carbon dioxide. Talanta 64:726-731

López-Cervantes J, Sánchez-Machado DI, Rosas-Rodríguez JA (2006) Analysis of free amino acids in fermented shrimp waste by high-performance liquid chromatography. J Chromatogr A 1105:106-110

Lordan S, Ross RP, Stanton C (2011) Marine bioactives as functional food ingredients: potential to reduce the incidence of chronic diseases. Mar Drugs 9(6):1056-1100

Lu Y, Shang Y, Huang X, Chen A, Yang Z, Jiang Y, Cai J, Gu W, Qian X, Yang H (2011) Preparation of strong cationic chitosan-graft-polyacrylamide flocculants and their flocculating properties. Ind Eng Chem Res 50(12):7141-7149

Maher T (2000) Astaxanthin. Continuing education module 1:1-5

Majid I, Nayik GA, Nanda V (2015) Ultrasonication and food technology: a review. Cogent Food Agric 1(1):1071022

Malho J-M, Heinonen H, Kontro I, Mushi NE, Serimaa R, Hentze H-P, Linder MB, Szilvay GR (2014) Formation of ceramophilic chitin and biohybrid materials enabled by a genetically engineered bifunctional protein. Chem Commun 50(55):7348-7351

Malmstena CL, Lignellb $\AA$ (2008) Dietary supplementation with astaxanthin-rich algal meal improves strength endurance-A double blind placebo controlled study on male students. J Carotenoid Sci 13:20-22

Manni L, Ghorbel-Bellaaj O, Jellouli K, Younes I, Nasri M (2010) Extraction and characterization of chitin, chitosan, and protein hydrolysates prepared from shrimp waste by treatment with crude protease from Bacillus cereus SV1. Appl Biochem Biotechnol 162(2):345-357

Marmon SK, Liljelind P, Undeland I (2009) Removal of lipids, dioxin and polychlorinated biphenyls during production of protein isolates from Baltic herring (Clupea harengus) using pH-shift process. J Agric Food Chem 57:7819-7825 
Mendes RL, Fernandes HI, Coelho JP, Reis EC, Cabral JM, Novais JM, Palavra AF (1995) Supercritical $\mathrm{CO}_{2}$ extraction of carotenoids and other lipids from Chlorella vulgaris. Food Chem 53:99-103

Mercadante AZ (2008) Analysis of carotenoids. In: Socaciu C, Presss CRC (eds) Food colorants: chemical and functionality. Taylor \& Francis. LLC, USA, pp 447-472

Meyers SP, Bligh D (1981) Characterization of astaxanthin pigment from heat processed crawfish waste. J Agric Food Chem 9:509-512

Meyers SP, Machada ZL (1978) Recovery of food-grade "waste" meat from the Spiny lobster Panulirus Argus. In: third annual tropical and subtropical fisheries technology conference of the America, Texas A\&M university. Texas, America

Miki W (1991) Biological functions and activities of animal carotenoids. Pure Appl Chem 63(1):141-146

Mina F, Mohammad C, Hamid V (2014) The anitoxidant effects of astaxanthin on quantitative and qualitative parameters of bull sperm. Indian J Fundam Appl Life Sci 4(4):425-430

Mir VG, Heinämäki J, Antikainen O, Revoredo OB, Colarte Al, Nieto OM, Yliruusi $J$ (2008) Direct compression properties of chitin and chitosan. Eur J Pharm Biopharm 69(3):964-968

Mir VG, Heinämäki J, Antikainen O, Sandler N, Revoredo OB, Colarte Al, Nieto OM, Yliruusi J (2010) Application of crustacean chitin as a co-diluent in direct compression of tablets. Am Assoc Pharm Sci 11(1):409-415

Mireles Dewitt CA, Gomez G, James JM (2002) Protein extraction from beef heart using acid solubilization. J Food Sci 67:3335-3341

Miyawaki H, Takahashi J, Tsukahara H, Takehara I (2008) Effects of astaxanthin on human blood rheology. J Clin Biochem Nutr 43(2):69-74

Muzzarelli RAA (1989) Amphoteric derivatives of chitosan and their biologica significances. In: Skjak-Braek G, Anthonsen T, Sandford P (eds) Chitin and chitosan. Elsevier Applied Science, New York, pp 87-99

Nagaki Y, Mihara M, Tsukahara H, Ono S (2006) The supplementation effect of astaxanthin on accommodation and asthenopia. J Clin Ther Med 22(1):41-54

Naito Y, Uchiyama K, Aoi W, Hasegawa G, Nakamura N, Yoshida N, Maoka T, Takahashi J, Yoshikawa T (2004) Prevention of diabetic nephropathy by treatment with astaxanthin in diabetic $\mathrm{db} / \mathrm{db}$ mice. BioFactors 20(1):49-59

Nguyen TT (2017) Biorefinery process development for recovery of functional and bioactive compounds from lobster processing by-products for food and nutraceutical applications. In: medical biotechnology, vol. Doctor, Flinders

Nguyen TT, Zhang W, Barber AR, Su P, He S (2015) Significant enrichment of polyunsaturated fatty acids (PUFAs) in the lipids extracted by supercritical $\mathrm{CO}_{2}$ from the livers of Australian rock lobsters (Jasus edwardsii). J Agric Food Chem 63(18):4621-4628

Nguyen TT, Zhang W, Barber AR, Su P, He S (2016) Microwave-intensified enzymatic deproteinization of Australian rock lobster shells (Jasus edwardsii) for the efficient recovery of protein hydrolysate as food functional nutrients. Food Bioprocess Technol 9(4):628-636

Nguyen TT, Barber AR, Luo X, Zhang W (2017) Application and optimization of the highly efficient and environmentally-friendly microwaveintensified lactic acid demineralization of deproteinized Rock lobster shells (Jasusedwardsii) for chitin production. Food Bioprod Process 102:367-374

Ni Y, Nagashimada M, Zhuge F, Zhan L, Nagata N, Tsutsui A, Nakanuma Y, Kaneko S, Ota T (2015) Astaxanthin prevents and reverses diet-induced insulin resistance and steatohepatitis in mice: a comparison with vitamin E. Sci Rep 5:1-15

Nir Y, Spiller G (2002) BioAstin helps relieve pain and improves performance in patients with rheumatoid arthritis. J Am Coll Nutr 21 (5):1-6

Nolsoe H, Undeland I (2009) The acid and alkaline solubilization process for the isolation of muscle proteins: state of art. Food Bioprocess Technol 2:1-27

Oh K-T, Kim Y-J, Jung W-J, Park R-D (2007) Demineralization of crab shell waste by Pseudomonas aeruginosa F722. Process Biochem 42(7):1069-1074

Osinga R, Tramper J, Wijffels RH (1999) Stability and stabilization of biocatalysts

Oviedo D, Garcia I, Mendez A, Henriques R (1982) Functional and nutritional evaluation of lobster shell soluble proteins. Food/Nahrung 26(4):391-395

Parajó JC, Dominguez H, Moure A, Diaz-Reinoso B (2008) Obtaining antioxidants by supercritical fluid extraction applied. In: Meireles AAA (ed)
Extracting bioactive compounds for food products: theory and applications. CRC Press, Taylor and Francis Group, LLC, USA

Park JS, Chyun JH, Kim YK, Line LL, Chew BP (2010) Astaxanthin decreased oxidative stress and inflammation and enhanced immune response in humans. Nutr Metab 7(18):1-10

Pathak A (2017) Chitin and chitosan; technology, applications and global market $\mathrm{BCC}$ research

Pathiraja IK (2014) Removal of acid yellow 25 dye onto chitin extracted from waste crab legs and study of adsorption isotherms and kinetics of AY25 dye adsorption. In: Chemistry, vol. Master, Southern Illinois University at Edwardsville

Peniche-Covas C, Alvarez L, Argüelles-Monal W (1992) The adsorption of mercuric ions by chitosan. J Appl Polym Sci 46(7):1147-1150

Percot A, Viton C, Domard A (2003) Optimization of chitin extraction from shrimp shells. Biomacromol 4(1):12-18

Peters RD, Sturz AV, MacLeod JA (2006) The benefits of using lobster processing waste as a soil amendment in organic potato production. In: guelph organic conference, natural sciences symposium Canada

Petit C, Reynaud S, Desbrieres I (2015) Amphiphilic derivatives of chitosan using microwave irradiation. Toward an eco-friendly process to chitosan derivatives. Carbohydr Polym 116:26-33

Pisuttharachai D, Fagutao FF, Yasuike M, Aono H, Yano Y, Murakami K, Kondo H, Aoki T, Hirono I (2009) Characterization of crustin antimicrobial proteins from Japanese spiny lobster Panulirus japonicus. Dev Comp Immunol 33(10):1049-1054

Pombo R (1995) Antifungal activity of lobster chitosan on growth of two phythogenic fungi. Congress of cell wall, Santiago De Compostela, Spain

Qi Z (2015) Biomimetic functional materials based on cellulose and chitin nanofibers. 2nd international conference on natural fibers, Portugeese

Rao AR, Sarada R, Ravishankar GA (2007) Stabilization of astaxanthin in edible oils and its use as an antioxidant. J Sci Food Agric 87(6):957-965

Reverchon E, De Marco I (2006) Supercritical fluid extraction and fractionation of natural matter. J Supercrit Fluids 38:146-166

Rinaudo M (2006) Chitin and chitosan: properties and applications. Prog Polym Sci 31(7):603-632

Rizliya V, Mendis E (2014) Biological, physical, and chemical properties of fish oil and industrial applications. In: Kim SK (ed) Seafood processing byproducts. Springer, Hiedelberg, pp 285-313

Ross RF (1927) The preparation of lobster paste. The ministry of Canadian marine and fisheries

Roy I, Mondal K, Gupta MN (2003) Accelerating enzymatic hydrolysis of chitin by microwave pretreatment. Biotechnol Prog 19(6):1648-1653

Rubio-Rodríguez N, De-Diego-Rupérez S, Beltrán S, Jaime I, Sanz MT, Rovira J (2008) Supercritical fluid extraction of the omega-3 rich oil contain in hake (Merluccius capensis-Merluccius paradoxus) by-products: study of influence of process parameters on the extraction yield and oil quality. J Supercrit Fluids 47:215-226

Rubio-Rodríguez N, Diego SMD, Beltrán S, Jaime I, Sanz MT, Rovira J (2012) Supercritical fluid extraction of fish oil from fish by-products: a comparison with other extraction methods. J Food Eng 109:238-248

Sachindra N, Bhaskar N, Siddegowda G, Sathisha A, Suresh P (2007) Recovery of carotenoids from ensilaged shrimp waste. Biores Technol 98(8):1642-1646

Safitri AU, Fajriah A, Astriandari A, Kartika I (2014) Bio mouth spray anti halitosis (bau mulut) berbasis fine particle chitosan lobster "segar sepanjang hari". Institute of Pertanian Bogor, Indonesia

Sahena F, Zaidul ISM, Jinap S, Saari N, Jahurul HA, Abbas KA, Norulaini NA (2009) PUFAs in fish: extraction, fractionation, importance in health. Compr Rev Food Sce Food Saf 8:59-74

Sahu A, Goswami P, Bora U (2009) Microwave mediated rapid synthesis of chitosan. J Mater Sci Mater Med 20(1):171-175

Saleem R, Hasnain A-U, Ahmad R (2015) Solubilisation of muscle proteins from chicken breast muscle by ultrasonic radiations in physiological ionic medium. Cogent Food Agric 1(1):1-11

Sandford PA (1989) Chitosan: commercial use and potential applications Elsevier Applied Science, London/New York

Savini I, Catani MV, Evangelista D, Gasperi V, Avigliano L (2013) Obesity-associated oxidative stress: strategies finalized to improve redox state. Int Mol Sci 14(5):10497-10538

Sayari N, Sila A, Abdelmalek BE, Abdallah RB, Ellouz-Chaabouni S, Bougatef A, Balti R (2016) Chitin and chitosan from the Norway lobster by-products: 
antimicrobial and anti-proliferative activities. Int J Biol Macromol 87:163-171

Seki T, Sueki H, Kono H, Kaoru S, Eiji Y (2001) Effects of astaxanthin from Haematococcus pluvialis on human skin. Fr J 12:98-103

Serrano GA, Narducci M (2014) Natural astaxanthin, antioxidant protection power for healthy eyes. Agro Food Ind High Technol 25:11-14

Seya Y, Takahashi J, Imanaka K (2009) Relationship between visual and reaction times - effects of a repetition of a visual task and long-term intake of a supplement food including astaxanthin on reaction time-Japanese. J Physiol Anthropol 14:17-24

Shahidi F (2006) Marine oils: compositional characteristics and health effects. In: nutraceutical and specialty lipids and their co-products, CRC Press

Shahidi F, Synowiecki J (1991) Isolation and characterization of nutrients and value-added products from snow crab (Chionoecetes opilio) and shrimp (Pandalus borealis) processing discards. J Agric Food Chem 39(8):1527-1532

Sharp RG (2013) A review of the applications of chitin and its derivatives in agriculture to modify plant-microbial interactions and improve crop yields. Agronomy 3(4):757-793

Shen M, Chen K, Lu J, Cheng P, Xu L, Dai W, Wang F, He L, Zhang Y, Chengfen W (2014) Protective effect of astaxanthin on liver fibrosis through modulation of TGF-1 expression and autophagy. Mediat Inflamm 2014:1-15

Silva GF, Gamarra FMC, Oliveira AL, Cabral FA (2008) Extraction of bisin from annatto seeds using supercritical carbon dioxide. Braz J Chem Eng 25:419-426

Simpson BK, Dauphin L, Smith JP (1993) Recovery and characteristics of carotenoprotein from lobster (Homarus americanus) waste. J Aquat Food Prod Technol 1(2):129-146

Sindhu S, Sherief P (2011) Extraction, characterization, antioxidant and antiinflammatory properties of carotenoids from the shell waste of Arabian red shrimp Aristeus alcocki. Open Conf Proc J. 2:95-103

Sini TK, Santhosh S, Mathew PT (2007) Study on the production of chitin and chitosan from shrimp shell by using Bacillus subtilis fermentation. Carbohydr Res 342(16):2423-2429

Sorokulova I, Krumnow A, Globa L, Vodyanoy V (2009) Efficient decomposition of shrimp shell waste using Bacillus cereus and Exiguobacterium acetylicum. J Ind Microbiol Biotechnol 36(8):1123-1126

Sunda F, Zhang Q, Zhang H, Zhang C, Qishan L (2012) Extraction method of astaxanthin from lobster heads, Google Patents

Swanson D, Block R, Mousa SA (2012) Omega-3 fatty acids EPA and DHA: health benefits throughout life. Adv Nutr Int Rev J 3(1):1-7

Synowiecki J, Al-Khateeb N (1997) Mycelia of Mucor rouxii as a source of chitin and chitosan. Food Chem 60:605-610

Synowiecki J, Al-Khateeb NA (2003) Production, properties, and some new applications of chitin and its derivatives. Crit Rev Food Sci Nutr 43:145-171

Tahergorabi R, Beamer S, Matak KE, Jaczynski J (2011) Effect of isoelectric solubilization/precipiation and titanium dioxide on whitening and texture of proteins recovered from dark chicken-meat processing by-products. Food Sci Technol 44(4):896-903

Tahergorabi R, Sivanandan L, Jaczynski J (2012) Dynamic rheology and endothermic transitions of proteins recovered from chicken-meat processing by-products using isolectric solubilization/preicpitation. Food Sci Technol 46(1):148-155

Tanaka Y, Ohkubo T (2003) Extraction of lipids from salmon roes with supercritical carbon dioxide. J Oleo Sci 52:295-301

Taskaya L, Chen YC, Beamer S, Tou JC, Jaczynski J (2009a) Composition characteristics of materials recovered from whole gutted silver carp (Hypophthalmichthys molitrix) using isoelectric solubilization/precipitation. J Agric Food Chem 57(10):4259-4266

Taskaya L, Chen YC, Jaczynski J (2009b) Functional properties of proteins recovered from whole gutted silver carp (Hypophthalmichthys molitrix) by isoelectric solubilization/precipitation. Food Sci Technol 42(6):1082-1089

Teo CC, Chong WPK, Ho YS (2013) Development and application of microwave-assisted extraction technique in biological sample preparation from small molecule analysis. Metabolomics 9:1109-1128

Tetens I (2009) Safety of 'lipid extract from Euphausia superba' as a novel food ingredient. Eur Food Saf Auth 938:1-17

Thériault G, Hanlon J, Creed L (2013) Report of the maritime lobster panel. Report to minister of agriculture, aquaculture and fisheries (New
Brunswick), Minister of fisheries and aquaculture (Nova Scotia), and minister of fisheries, aquaculture and rural development (Prince Edward Island), Canada

Tominaga K, Hongo N, Karato M, Yamashita E (2012) Cosmetic benefits of astaxanthin on humans subjects. Acta Biochim Pol 59(1):43

Tong-Xun L, Mou-Ming Z (2010) Thermal pretreatment and chemical modifications as a mean to alter hydrolytic characteristics and prevent bitterness in hydrolysates of fishery by-catch (Decapterus maruadsi) protein. Int J Food Sci Technol 45:1852-1861

Torrissen O, Tidemann E, Hansen F, Raa J (1981) Ensiling in acid—a method to stabilize astaxanthin in shrimp processing by-products and improve uptake of this pigment by rainbow trout (Salmo gairdneri). Aquaculture 26(1-2):77-83

Tsvetnenko E, Kailis S, Evans L, Longmore R (1996) Fatty acid composition of lipids from the contents of rock lobster (Panulirus cygnus) cephalothorax. J Am Oil Chem Soc 73(2):259-261

Tu Y (1991) Recovery, drying and characterization of carotenoproteins from industrial lobster waste. In: food science and agriculture chemistry, vol. Master of Science, McGill University

Tu Y, Simpson BK, Ramaswamy H, Yaylayan V, Smith JP, Hudon C (1991) Carotenoproteins from lobster waste as a potential feed supplement for cultured salmonids. Food Biotechnol 5(2):87-93

Tu Z-C, Huang T, Wang H, Sha X-M, Shi Y, Huang X-Q, Man Z-Z, Li D-J (2015) Physico-chemical properties of gelatin from bighead carp (Hypophthalmichthys nobilis) scales by ultrasound-assisted extraction. J Food Sci Technol 52(4):2166-2174

Uchiyama K, Naito Y, Hasegawa G, Nakamura N, Takahashi J, Yoshikawa T (2002) Astaxanthin protects $\beta$-cells against glucose toxicity in diabetic $\mathrm{db} / \mathrm{db}$ mice. Redox Rep 7(5):290-293

Undeland I, Kelleher SD, Hultin HO (2002) Recovery of functional proteins from herring light muscle by an acid or alkaline solubilization process. J Agric Food Chem 50:7371-7379

Valdez-Pena AU, Espinoza-Perez JD, Sandoval-Fabian GC, Balagurusamy N, Hernandez-Rivera A, De-la-Garza-Rodriguez IM, Contreras-Esquivel JC (2010) Screening of industrial enzymes for deproteinisation of shrimp head for chitin recovery. Food Science Biotechnol 19(2):553-557

Vardanega R, Santos DT, Meireles MAA (2014) Intensification of bioactive compounds extraction from medicinal plants using ultrasonic irradiation. Pharmacogn Rev 8(16):88

Venugopal V (2009) Functional and bioactive nutraceutical compounds from the ocean. In: Mazza G (ed) Marine products for healthcare. CRC Press/ Taylor \& Francis, Boca Raton

Venugopal V, Shahidi F (1995) Value-added products from underutilized fish species. Rev Food Sci Nutr 35(5):431-453

Vieira GH, Martin AM, Saker-Sampaiao S, Omar S, Goncalves RC (1995) Studies on the enzymatic hydrolysis of Brazilian lobster (Panulirus spp) processing wastes. J Sci Food Agric 69(1):61-65

Vilkhu K, Mawson R, Simons L, Bates D (2008) Applications and opportunities for ultrasound assisted extraction in the food industry - A review. Innov Food Sci Emerg Technol 9(2):161-169

Wang S-L, Chio S-H (1998) Deproteinization of shrimp and crab shell with the protease of Pseudomonas aeruginosa K-187. Enzyme Microb Technol 22(7):629-633

Wasikiewicz JM, Yeates SG (2013) "Green" molecular weight degradation of chitosan using microwave irradiation. Polym Degrad Stab 98(4):863-867

Wibowo S, Velazquez G, Savant V, Torres JA (2007) Effect of chitosan type on protein and water recovery efficiency from surimi wash water treated with chitosan-alginate complexes. Biores Technol 98(3):539-545

Wijesekara I, Kim S-K (2010) Angiotensin-l-converting enzyme (ACE) inhibitors from marine resources: prospects in the pharmaceutical industry. Mar Drugs 8(4):1080-1093

Xu Y, Gallert C, Winter J (2008) Chitin purification from shrimp waste by microbial deproteinisation and decalcification. Appl Microbiol Biotechnol 79:687-697

Hayes M (2012) Chitin, chitosan and their derivatives from marine rest raw materials: potential food and pharmaceutical applications. In: Hayes M (ed) Marine bioactive compounds: sources, characterization and applications. Springer, USA

Sabatini P (2015) Lobster-commodity update. Globefish, FAO

Yamashita $E$ (2005) The effects of a dietary supplement containing astaxanthin on skin condition. Food Style 21 9(9):72-80 
Yamashita E (2011) Astaxanthin and sports performance. Food Style 21:15-20 Yamashita E (2013) Astaxanthin as a medical food. Funct Foods Health Dis 3(7):254-258

Yan N, Chen X (2015) Don't waste seafood waste. Nature 254:155-157

Yilmaz B, Sahin K, Bilen H, Bahcecioglu IH, Bilir B, Ashraf S, Halazun KJ, Kucuk O (2015) Carotenoids and non-alcoholic fatty liver disease. Hepatobiliary Surg Nutr 4(3):161-171

Yook JS, Okamoto M, Rakwal R, Shibato J, Lee MC, Matsui T, Chang HK, Cho $J Y$, Soya H (2015) Astaxanthin supplementation enhances adult hippocampal neurogenesis and spatial memory in mice. Mol Nutr Food Res 3(60):589-599

Zhang J, Yan N (2016) Formic acid-mediated liquefaction of chitin. Green Chem 18(18):5050-5058
Zhang X-S, Zhang X, Wu Q, Li W, Zhang Q-R, Wang C-X, Zhou X-M, Li H, Shi J-X, Zhou M-L (2014a) Astaxanthin alleviates early brain injury following subarachnoid hemorrhage in rats: possible involvement of Akt/bad signaling. Mar Drugs 12(8):4291-4310

Zhang X-S, Zhang X, Zhou M-L, Zhou X-M, Li N, Li W, Cong Z-X, Sun Q, Zhuang Z, Wang C-X (2014b) Amelioration of oxidative stress and protection against early brain injury by astaxanthin after experimental subarachnoid hemorrhage: laboratory investigation. J Neurosurg 121(1):42-54

\section{Submit your manuscript to a SpringerOpen ${ }^{\circ}$ journal and benefit from:}

- Convenient online submission

- Rigorous peer review

- Open access: articles freely available online

- High visibility within the field

- Retaining the copyright to your article

Submit your next manuscript at $\boldsymbol{\nabla}$ springeropen.com 